\title{
Uncertainties in isoprene photochemistry and emissions: implications for the oxidative capacity of past and present atmospheres and for climate forcing agents
}

\author{
P. Achakulwisut ${ }^{1}$, L. J. Mickley ${ }^{2}$, L. T. Murray $^{3,4}$, A. P. K. Tai ${ }^{5}$, J. O. Kaplan $^{6}$, and B. Alexander ${ }^{7}$ \\ ${ }^{1}$ Department of Earth and Planetary Sciences, Harvard University, Cambridge, MA, USA \\ ${ }^{2}$ School of Engineering and Applied Sciences, Harvard University, Cambridge, MA, USA \\ ${ }^{3}$ NASA Goddard Institute for Space Studies, New York, NY, USA \\ ${ }^{4}$ Lamont-Doherty Earth Observatory, Columbia University, Palisades, NY, USA \\ ${ }^{5}$ Earth System Science Programme, The Chinese University of Hong Kong, Hong Kong, China \\ ${ }^{6}$ ARVE Group, École Polytechnique Fédérale de Lausanne, Lausanne, Switzerland \\ ${ }^{7}$ Department of Atmospheric Sciences, University of Washington, Seattle, WA, USA
}

Correspondence to: P. Achakulwisut (pachakulwisut@fas.harvard.edu)

Received: 29 December 2014 - Published in Atmos. Chem. Phys. Discuss.: 23 January 2015

Revised: 9 June 2015 - Accepted: 11 June 2015 - Published: 20 July 2015

\begin{abstract}
Isoprene and its oxidation products are major players in the oxidative chemistry of the troposphere. Current understanding of the factors controlling biogenic isoprene emissions and of the fate of isoprene oxidation products in the atmosphere has been evolving rapidly. We use a climate-biosphere-chemistry modeling framework to evaluate the sensitivity of estimates of the tropospheric oxidative capacity to uncertainties in isoprene emissions and photochemistry. Our work focuses on two climate transitions: from the Last Glacial Maximum (LGM, 19000-23 000 years BP) to the preindustrial (1770s) and from the preindustrial to the present day (1990s). We find that different oxidants have different sensitivities to the uncertainties tested in this study. Ozone is relatively insensitive, whereas $\mathrm{OH}$ is the most sensitive: changes in the global mean $\mathrm{OH}$ levels for the LGM-to-preindustrial transition range between -29 and $+7 \%$ and those for the preindustrial-to-present-day transition range between -8 and $+17 \%$ across our simulations. We find little variability in the implied relative LGMpreindustrial difference in methane emissions with respect to the uncertainties tested in this study. Conversely, estimates of the preindustrial-to-present-day and LGM-to-preindustrial changes in the global burden of secondary organic aerosol (SOA) are highly sensitive. We show that the linear relationship between tropospheric mean $\mathrm{OH}$ and tropospheric
\end{abstract}

mean ozone photolysis rates, water vapor, and total emissions of $\mathrm{NO}_{x}$ and reactive carbon - first reported in Murray et al. (2014) - does not hold across all periods with the new isoprene photochemistry mechanism. This study demonstrates how inadequacies in our current understanding of isoprene emissions and photochemistry impede our ability to constrain the oxidative capacities of the present and past atmospheres, its controlling factors, and the radiative forcing of some short-lived species such as SOA over time.

\section{Introduction}

A key player in the coupling between climate change and atmospheric chemical composition is the oxidative capacity of the troposphere, primarily characterized by the burden of the four most abundant and reactive oxidants: $\mathrm{OH}$, ozone, $\mathrm{H}_{2} \mathrm{O}_{2}$, and $\mathrm{NO}_{3}$. Estimates of the oxidative capacity of past atmospheres remain uncertain due to the limited number of historical and paleo-observations, which hinders our ability to understand the chemical, climatic, and ecological consequences of past changes in the oxidative capacity. Multiple factors govern the abundance of tropospheric oxidants, including emissions of reactive volatile organic compounds (VOCs). Isoprene (2-methyl-1,3-butadiene, $\mathrm{C}_{5} \mathrm{H}_{8}$ ), primarily emitted 
by plants, is the most abundant VOC in the present-day atmosphere after methane (Pike and Young, 2009). Recent studies have suggested the need to revise our understanding of the environmental factors controlling biogenic isoprene emissions and of its atmospheric photo-oxidation mechanism (e.g., Paulot et al., 2009a, b; Possell and Hewitt, 2011). These advances call into question the validity of existing model estimates of the oxidative capacity of past atmospheres. In this study, we use a climate-biosphere-chemistry modeling framework (Murray et al., 2014) to explore the sensitivity of the simulated oxidative capacity to uncertainties in isoprene emissions and photochemistry and the implications for radiative forcing on preindustrial-present and on glacialinterglacial timescales. To our knowledge, this study is the first systematic evaluation of the effects of these recent developments on model estimates of the chemical composition of past atmospheres.

The atmospheric oxidative capacity determines the lifetime of many trace gases important to climate, chemistry, and human health (e.g., Isaksen and Dalsøren, 2011; Fiore et al., 2012). It may also induce oxidative stress or alter the deposition of oxidized nutrients to terrestrial and marine ecosystems (Sitch et al., 2007; Paulot et al., 2013). Furthermore, oxidants modify the radiative effects of aerosols by influencing their evolution, lifetime, and physical properties (Sofen et al., 2011). However, due to the high reactivity of most atmospheric oxidants, direct measurement of their past abundances is not currently possible for most species. Late 19th-century surface ozone measurements exist but their accuracy has been debated (Pavelin et al., 1999). Atmospheric oxidants, except for $\mathrm{H}_{2} \mathrm{O}_{2}$, are not directly preserved in the ice-core record. Even for $\mathrm{H}_{2} \mathrm{O}_{2}$, however, postdepositional processes impede quantitative interpretation of this record (Hutterli et al., 2002). As summarized in Murray et al. (2014), Table 1, prior modeling studies that investigated past changes in the abundance of tropospheric oxidants disagree on the magnitude and even the sign of change. Such discrepancies call into question our ability to quantify the relative roles of sources and sinks in driving past variations in atmospheric methane concentrations. Previous studies attributed these variations to changes in wetland emissions, the dominant natural source of methane to the atmosphere (e.g., Khalil and Rasmussen, 1987; Brook et al., 2000). However, more recent modeling studies suggested that potential variations in $\mathrm{OH}$ - the primary sink for methane - may be larger than previously thought, driven by changes in biogenic VOC emissions (e.g., Kaplan, 2002; Valdes et al., 2005; Harder et al., 2007). This issue remains an ongoing debate (e.g., Levine et al., 2011b; Quiquet et al., 2015).

Tropospheric oxidants are strongly coupled through atmospheric photochemical reactions, and their abundances respond to meteorological conditions, changes in surface and stratospheric boundary conditions, and changes in emissions of key chemical species such as reactive nitrogen oxides $\left(\mathrm{NO}_{x}=\mathrm{NO}+\mathrm{NO}_{2}\right)$ and VOCs. Present-day natural emis- sions of VOCs, which far exceed those from anthropogenic sources on a global scale, are dominated by plant isoprene emissions, which have an estimated global source ranging from approximately 500 to $750 \mathrm{Tg} \mathrm{yr}^{-1}$ (Lathière et al., 2005; Guenther et al., 2006). This large emission burden is accompanied by high reactivity; isoprene has an atmospheric chemical lifetime on the order of minutes to hours (Pike and Young, 2009). Isoprene and its oxidation products react with $\mathrm{OH}$, ozone, and the nitrate radical and are thus major players in the oxidative chemistry of the troposphere (Beerling et al., 2007). The oxidation products of isoprene also substantially contribute to secondary organic aerosol (SOA) formation (Henze and Seinfeld, 2006). Biogenic SOA, like other aerosols, affects climate by scattering and absorbing solar radiation and by altering the properties and lifetimes of clouds, but the net climate effect is poorly characterized (Scott et al., 2014). Therefore, uncertainties in the preindustrial-topresent-day changes in biogenic VOC emissions, and subsequently in SOA burdens, lead to large uncertainties in the anthropogenic indirect radiative forcing estimates over the industrial period (e.g., Carslaw et al., 2013; Scott et al., 2014).

Results from the Atmospheric Chemistry and Climate Model Intercomparison Project (ACCMIP) demonstrate that uncertainties remain in our understanding of the long-term trends in $\mathrm{OH}$ and methane lifetime and that these uncertainties primarily stem from a lack of adequate constraints on natural precursor emissions and on the chemical mechanisms in the current generation of chemistry-climate models (Naik et al., 2013). Recent field and laboratory findings have called into question prior estimates of global isoprene burdens for the past and future atmospheres and have revealed new details of the isoprene photo-oxidation mechanism. First, isoprene emission from plants is well known to be strongly dependent on plant species and, for a given species, on environmental factors including temperature, light availability, and leaf age (Guenther et al., 2012). However, recent empirical studies have shown that isoprene emission by several plant taxa is also inversely correlated with atmospheric $\mathrm{CO}_{2}$ levels, but this relationship is not yet well constrained (e.g., Wilkinson et al., 2009; Possell and Hewitt, 2011). The biochemical mechanism for this effect remains unresolved, but evidence suggests that $\mathrm{CO}_{2}$ concentration plays a role in partitioning carbon-substrate availability between the chloroplast and cytosol of a plant cell and in mobilizing stored carbon sources (Trowbridge et al., 2012). Such bio-mechanisms involving a $\mathrm{CO}_{2}$ dependence of isoprene emissions may have evolved in plants long ago.

Second, recent field studies in major isoprene-emitting regions, such as the Amazon forest (Lelieveld et al., 2008), South East Asia (Hewitt et al., 2010) and China (Hofzumahaus et al., 2009), reported large discrepancies between measured and modeled $\mathrm{HO}_{x}\left(\mathrm{OH}+\mathrm{HO}_{2}\right)$ concentrations, suggesting that $\mathrm{VOC}$ oxidation under low- $\mathrm{NO}_{x}$ conditions may recycle $\mathrm{OH}$ more efficiently than previously understood. These findings motivated numerous theoretical and exper- 
imental studies, which in turn led to extensive updates in the gas-phase isoprene photo-oxidation mechanism, in which there is greater regeneration and recycling of $\mathrm{HO}_{x}$ and $\mathrm{NO}_{x}$ under high- $\mathrm{NO}_{x}$ conditions and of $\mathrm{HO}_{x}$ under low- $\mathrm{NO}_{x}$ conditions (e.g., Paulot et al., 2009a, b). In general, greater $\mathrm{OH}-$ recycling enhances the efficiency of atmospheric oxidation, while greater $\mathrm{NO}_{x}$-recycling enhances the efficiency of ozone production. However, the improved mechanism is still unable to fully reconcile measured and modeled $\mathrm{OH}$ concentrations (Mao et al., 2012). Moreover, global and regional modeling studies indicate that the heterogeneous $\mathrm{HO}_{2}$ uptake by aerosols presents a potentially important $\mathrm{HO}_{x}$ sink. There remains, however, considerable uncertainty in the magnitude of this sink and its impact on tropospheric chemistry (Thornton et al., 2008). Mao et al. (2013a) proposed a new scheme in which $\mathrm{HO}_{2}$ uptake by aerosols leads to $\mathrm{H}_{2} \mathrm{O}$ rather than $\mathrm{H}_{2} \mathrm{O}_{2}$ formation via coupling of $\mathrm{Cu}$ (I) $/ \mathrm{Cu}$ (II) and $\mathrm{Fe}$ (II) $/ \mathrm{Fe}$ (III) ions. Since $\mathrm{H}_{2} \mathrm{O}_{2}$ can be readily photolyzed to regenerate $\mathrm{OH}$, this new mechanism provides a more efficient $\mathrm{HO}_{x}$ removal pathway. $\mathrm{Cu}$ and $\mathrm{Fe}$ are ubiquitous components of crustal and combustion aerosols (Mao et al., 2013a). Observations and model studies suggest that during the Last Glacial Maximum (LGM) and preindustrial, natural dust distributions were higher than that in the present day (Mahowald et al., 2006). In particular, during the LGM, $\mathrm{Fe}$ (II) and $\mathrm{Fe}$ (III) ion concentrations in dust increased by at least 2 times relative to interglacial levels (Spolaor et al., 2013). Likewise, positive $\mathrm{Cu}$ anomalies during the last glacial period have been measured in ice cores (Oyarzun et al., 2005).

In support of the ICE age Chemistry And Proxies (ICECAP) project, Murray et al. (2014) developed a new climatebiosphere-chemistry modeling framework for simulating the chemical composition of the present and past tropospheres, focusing on preindustrial-to-present and glacial-interglacial transitions. The Last Glacial Maximum $(\sim 19-23 \mathrm{ka})$ spans the coldest interval of the last glacial period $(\sim 11.5-110 \mathrm{ka})$ and is relatively well recorded in ice-core and sediment records, making the LGM-to-preindustrial transition a convenient glacial-interglacial analogue. Disparities in existing model studies of past tropospheric oxidant levels are partly due to differences in the model components of the Earth system allowed to vary with climate and the differing degrees of complexity in the representation of those components (Murray et al., 2014). The ICECAP project is the first 3-D model framework to consider the full suite of key factors controlling the oxidative capacity of the troposphere at and since the LGM, including the effect of changes in the stratospheric column ozone on tropospheric photolysis rates. Murray et al. (2014) found that (1) the oxidative capacities of the preindustrial and LGM atmospheres were both lower than that of the present day; (2) tropospheric mean $\mathrm{OH}$ levels appear to be well buffered in the LGM-to-preindustrial transition - a result at odds with most prior studies; (3) past changes in atmospheric methane concentrations were predominantly source driven; and (4) the key parameters controlling the oxidative capacity over LGM-present-day timescales are tropospheric mean ozone photolysis rates, water vapor abundance, and total emissions of $\mathrm{NO}_{x}$ and reactive carbon.

In light of recent developments in our understanding of the isoprene photo-oxidation mechanism and of the sensitivity of plant isoprene emissions to atmospheric $\mathrm{CO}_{2}$ levels, we build on the model study by Murray et al. (2014) to explore the sensitivity of the simulated tropospheric oxidative capacity at and since the LGM and the ramifications for our understanding of the factors controlling the oxidative capacity. We also discuss the implications for changes in short-lived climate forcers and for interpreting the ice-core methane record. We examine, in a systematic manner, the effects of all of the above developments on the chemical composition of the troposphere over the last glacial-interglacial time interval and the industrial era.

\section{Methods: model framework, model developments, and project description}

\subsection{The ICECAP model framework}

Figure 1 illustrates the stepwise, offline-coupled climatebiosphere-chemistry model framework of the ICECAP project. This setup relies on four global models. GEOSChem is a global 3-D chemical transport model (CTM) with a long history in simulating present-day tropospheric ozone- $\mathrm{NO}_{x}-\mathrm{CO}-\mathrm{VOC}-\mathrm{BrO}_{x}$-aerosol chemistry (http://www.geos-chem.org; Bey et al., 2001; Park et al., 2004; Parrella et al., 2012). The version used here includes online linearized stratospheric chemistry (McLinden et al., 2000), which allows for calculation of photolysis rates more consistent with changing climate and chemical conditions. We use version 9-01-03 with modifications as described in Murray et al. (2014) and below. ICECAP is driven by meteorological fields from ModelE, a climate model developed at the NASA Goddard Institute of Space Studies (GISS). ModelE and related models at GISS have been used extensively in paleo-climate studies (e.g., LeGrande et al., 2006; Rind et al., 2001, 2009). Here we use the ModelE version with a horizontal resolution of $4^{\circ}$ latitude by $5^{\circ}$ longitude and 23 vertical layers extending from the surface to $0.002 \mathrm{hPa}$ in the atmosphere. Climate in ModelE is forced by prescribed greenhouse gas levels, orbital parameters, topography, and sea ice and sea surface temperatures (SSTs) relevant to each time slice of interest. The final components are the BIOME4-trace-gas (BIOME4-TG) equilibrium terrestrial biosphere model (Kaplan et al., 2006) and the LundPotsdam-Jena Lausanne-Mainz fire (LPJ-LMfire) dynamic global vegetation model (Pfeiffer et al., 2013). BIOME4TG is used to determine static vegetation distributions, while LPJ-LMfire simulates biomass burning regimes. Meteorology from ModelE drives both these models, and the result- 


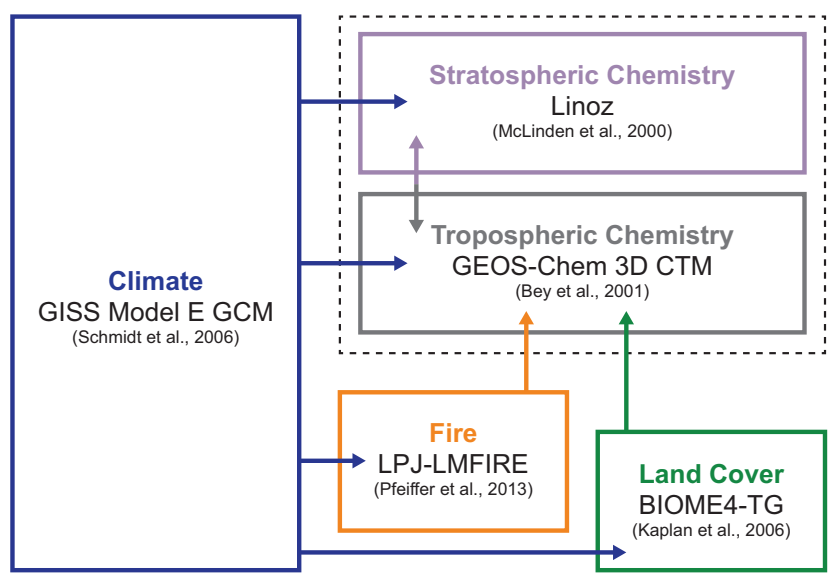

Figure 1. The ICE age Chemistry And Proxies (ICECAP) model framework consists of four global models, represented here by boxes with solid lines. The stratospheric and tropospheric chemistry schemes are coupled online in the GEOS-Chem chemical transport model (CTM). Arrows indicate the flow of model output. The ICECAP model framework was especially designed for simulating the oxidative capacity of past atmospheres. (Adapted from Murray et al., 2014, Fig. 1.)

ing land-cover characteristics and dry matter burned are implemented into GEOS-Chem. The basal biogenic emission factors per plant functional types used in the BIOME4-TG model, which do not change between the climate scenarios, can be found in Murray et al. (2014), Table 5 .

A detailed description of the ICECAP model framework and its evaluation against observations can be found in Murray et al. (2014). The present-day simulation has been evaluated against a suite of sonde, aircraft, satellite, and surface measurements of trace gases, aerosols, and radionuclides. The simulated LGM climate scenarios have also been evaluated against pollen-based climate reconstruction from Bartlein et al. (2011). The ICECAP model overestimates transport from the stratosphere due to an overly vigorous Brewer-Dobson circulation (Murray et al., 2014). Rather than fixing the transport fluxes to better match present-day values, we accept this bias in order to allow the stratospheric columns of ozone to adjust freely to different climate scenarios. For example, Murray et al. (2014) found that reductions in greenhouse gases weaken the stratospheric residual circulation and lead to an increase in tropical stratospheric ozone columns.

As in Murray et al. (2014), we perform simulations for four different climate scenarios: present day (ca. 1990s), preindustrial (ca. 1770s), and two different representations of the LGM $(\sim 19-23 \mathrm{ka})$ to span the range of likely conditions. The simulated average global surface air temperatures are $14.9^{\circ} \mathrm{C}$ for the present day, $14.3^{\circ} \mathrm{C}$ for the preindustrial, $10.7^{\circ} \mathrm{C}$ for the warm LGM, and $6.1^{\circ} \mathrm{C}$ for the cold LGM (Murray et al., 2014, Table 4). The two LGM scenarios differ in the degree of cooling of tropical SSTs. Such differences have implications for LGM dynamics because of the influence of tropical SSTs on meridional temperature gradients and low-latitude circulation (Rind et al., 2009). The "warm LGM" uses SST reconstructions from the Climate: Long range Investigation, Mapping, and Prediction project (CLIMAP Project Members, 1976), with an average change in SST within $15^{\circ}$ of the Equator relative to the prein-

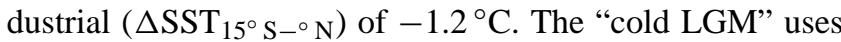

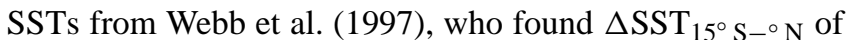
$-6.1^{\circ} \mathrm{C}$. By imposing an ocean heat transport flux in an earlier version of the GISS model, Webb et al. (1997) achieved a better match with certain paleo-proxies of temperature such as corals (Guilderson et al., 1994; Stute et al., 1995). The warm LGM SSTs yield a change of mean global surface air temperature of $-3.6^{\circ} \mathrm{C}$ relative to the preindustrial, while the cold LGM SSTs yield a change of $-8.2^{\circ} \mathrm{C}$. These values lie within the range of temperature changes reported by Holden et al. (2010), and they span the approximately $-7^{\circ} \mathrm{C}$ change inferred from Gildor et al. (2014) for the LGM relative to the present day. The MARGO project, which is the current best assumption of tropical SSTs at the LGM, found $\Delta \mathrm{SST}_{15^{\circ} \mathrm{S}-{ }^{\circ} \mathrm{N}}$ of $-1.7 \pm 1.0^{\circ} \mathrm{C}$ (Waelbroeck et al., 2009). These estimates are more similar to the warm LGM than the cold LGM scenario used in this study.

Murray et al. (2014) also tested the sensitivity of their model results to uncertainties in lightning and fire emissions. Comparison with paleo-observations suggests that their "low-fire, variable-lightning, warm LGM" scenario was the best representation of the LGM atmosphere, in which lightning $\mathrm{NO}_{x}$ emissions are parameterized to reflect changes in convective cloud top heights, and the LPJLMfire fire emissions are scaled to match observational records inferred from the Global Charcoal Database (Power et al., 2007, 2010). The model simulations in this study are performed using the Murray et al. (2014) "best estimate" fire and lightning emission scenarios relevant for each climate.

\subsection{Uncertainties in biogenic isoprene emissions}

Biogenic VOC emissions in GEOS-Chem are calculated interactively by the Model of Emissions of Gases and Aerosols from Nature (MEGAN v2.1) (Guenther et al., 2012). The canopy-level flux of isoprene is computed as a function of plant function type (PFT)-specific basal emission rate, scaled by activity factors $\left(\gamma_{i}\right)$ to account for environmental controlling factors including temperature, light availability, leaf age, and leaf area index. Tai et al. (2013) recently implemented an additional activity factor, $\gamma_{\mathrm{C}}$, to account for the effect of atmospheric $\mathrm{CO}_{2}$ concentrations. They used the empirical relationship from Possell and Hewitt (2011): $\gamma_{\mathrm{C}}=a /(1+a b C)$, where the fitting parameters $a$ and $b$ have values of 8.9406 and $0.0024 \mathrm{ppm}^{-1}$, respectively, and $C$ represents the atmospheric $\mathrm{CO}_{2}$ concentration $\left(\gamma_{\mathrm{C}}=1\right.$ at $\left.C=370 \mathrm{ppm}\right)$. To date, Possell and Hewitt (2011) studied the widest range of plant taxa and atmospheric $\mathrm{CO}_{2}$ concentrations. Their $\mathrm{CO}_{2}-$ 
isoprene emission response curve shows a higher sensitivity at $\mathrm{CO}_{2}$ concentrations below present-day levels than others from similar studies (e.g., Wilkinson et al., 2009), likely providing an upper limit of this effect for past climates. We have not considered the effect of $\mathrm{CO}_{2}$ sensitivity on other plant VOC emissions, such as monoterpenes and sesquiterpenes, due to lack of conclusive evidence of this effect (Peñuelas and Staudt, 2010). In all four climate scenarios, isoprene constitutes more than $60 \%$ of total biogenic VOC emissions.

In this study, we follow the Tai et al. (2013) implementation, which uses the empirical relationship from Possell and Hewitt (2011). Table 1 summarizes the prescribed $\mathrm{CO}_{2}$ mixing ratios, as well as the estimated total annual isoprene burdens with and without consideration of the $\mathrm{CO}_{2}$ sensitivity of plant isoprene emissions, for each climate scenario. When the $\mathrm{CO}_{2}$ sensitivity is considered, we find relative increases in the total biogenic isoprene source of $4 \%$ for the present day, $28 \%$ for the preindustrial, $78 \%$ for the warm LGM, and $77 \%$ for the cold LGM scenarios.

\subsection{Uncertainties in the fate of the oxidation products of isoprene}

\subsubsection{Isoprene photo-oxidation mechanism}

Murray et al. (2014) used the original GEOS-Chem isoprene photo-oxidation mechanism, which is largely based on Horowitz et al. (1998). Here we apply recent updates to the mechanism by Mao et al. (2013b) and Paulot et al. (2009a, b), which Mao et al. (2013b) evaluated in GEOS-Chem through comparison with present-day observations of ozone, isoprene, and oxidation products. Daytime oxidation of isoprene by $\mathrm{OH}$ leads to the formation of hydroxyl-peroxy radicals $\left(\mathrm{ISOPO}_{2}\right)$. The new scheme includes a more explicit treatment of the production and subsequent reactions of organic nitrates, acids, and epoxides from reactions of the $\mathrm{ISOPO}_{2}$ radicals. Such reactions lead to greater $\mathrm{HO}_{x}$ - and $\mathrm{NO}_{x}$-regeneration and recycling than in the original mechanism, especially under low- $\mathrm{NO}_{x}$ conditions, which is of particular relevance for past atmospheres (Mao et al., 2013b). The new scheme also includes an update for the aerosol reactive uptake coefficient of $\mathrm{NO}_{3}$ radicals, in which the value is increased from $10^{-4}$ to 0.1 (Mao et al., 2013b). Beyond Mao et al. (2013b), we also change the stoichiometry of the $\left(\mathrm{ISOPO}_{2}+\mathrm{HO}_{2}\right)$ reaction to that recommended by the laboratory study of Liu et al. (2013), which has smaller uncertainties and leads to relatively smaller yields (by $\sim 50 \%$ ) of $\mathrm{HO}_{x}$, methyl vinyl ketone, and methacrolein from this pathway. Our work tests the sensitivity of model results to these updates in the isoprene photo-oxidation mechanism.

\subsubsection{Heterogeneous $\mathrm{HO}_{2}$ uptake by aerosols}

As parameterized in the standard GEOS-Chem model, gaseous $\mathrm{HO}_{2}$ uptake by aqueous aerosols leads to $\mathrm{H}_{2} \mathrm{O}_{2}$ for- mation and has a $\gamma\left(\mathrm{HO}_{2}\right)$ value typically less than 0.1 , where $\gamma\left(\mathrm{HO}_{2}\right)$ is a measure of the efficacy of uptake, defined as the fraction of $\mathrm{HO}_{2}$ collisions with aerosol surfaces resulting in reaction. (Note that $\gamma$ traditionally refers to both the aerosol uptake efficiency and biogenic emissions flux activity factor.) Atmospheric observations, however, suggest that $\mathrm{HO}_{2}$ uptake by aerosols may in fact not produce $\mathrm{H}_{2} \mathrm{O}_{2}$ (de Reus et al., 2005; Mao et al., 2010). In light of these findings, Mao et al. (2013a) implemented a new uptake scheme in GEOS-Chem in which $\mathrm{HO}_{2}$ uptake yields $\mathrm{H}_{2} \mathrm{O}$ via coupling of $\mathrm{Cu}(\mathrm{I}) / \mathrm{Cu}(\mathrm{II})$ and $\mathrm{Fe}(\mathrm{II}) / \mathrm{Fe}(\mathrm{III})$ ions, and we follow that approach here. As in Mao et al. (2013a), we use the upper limit of $\gamma\left(\mathrm{HO}_{2}\right)=1.0$ for all aerosol types to evaluate the implications of this uptake for the $\mathrm{HO}_{x}$ budgets and for the fate of the oxidation products of isoprene.

\subsection{Outline of model sensitivity experiments}

Table 2 summarizes the different climate, chemistry, and plant isoprene emission scenarios tested in this model study. For each climate scenario, we apply to GEOS-Chem the archived meteorology and land-cover products from the "best estimate" fire and lightning emission scenarios from Murray et al. (2014). We test three different chemistry schemes in GEOS-Chem: C1 uses the original isoprene chemistry and original $\mathrm{HO}_{2}$ uptake, $\mathrm{C} 2$ uses the new isoprene chemistry and original $\mathrm{HO}_{2}$ uptake, and $\mathrm{C} 3$ uses the new isoprene chemistry and new $\mathrm{HO}_{2}$ uptake mechanisms. Each chemistry scheme is tested either with (w) or without (wo) inclusion of the $\mathrm{CO}_{2}$ sensitivity of biogenic isoprene emissions, except for the present day. As Table 1 shows, consideration of the $\mathrm{CO}_{2}$ sensitivity for the present day results in only a $4 \%$ change in the global isoprene burden $\left(\gamma_{\mathrm{C}}=1\right.$ at $\left.C=370 \mathrm{ppm}\right)$, and so we assume that the present-day model simulations with consideration of the $\mathrm{CO}_{2}$ sensitivity of biogenic isoprene emissions are representative of their respective "without" scenarios. Our "C1-wo" model simulations match the isoprene emissions and photochemistry schemes used by Murray et al. (2014). We perform 21 simulations in total.

For each climate scenario, we use 4 subsequent years of archived meteorology from the GISS climate model. Each GEOS-Chem simulation is initialized with a 10-year spin-up, repeatedly using the first year of archived meteorology, to reach equilibrium with respect to stratosphere-troposphere exchange. We then perform 3 more years of simulations for analysis, using the 3 subsequent years of archived meteorology. All of the quantities considered here are global means or averages over large spatial regions. We find that the interannual variability of such quantities is small compared to the differences between the climate scenarios, and that 3 years is sufficient for our analysis.

In GEOS-Chem, atmospheric methane concentrations are prescribed with imposed meridional gradients derived from observations, except for the tropical LGM in which model results are used (Murray et al., 2014, Table 3). The tropospheric 
(a) $\mathrm{OH}\left(10^{5}\right.$ molecules $\left.\mathrm{cm}^{-3}\right)$

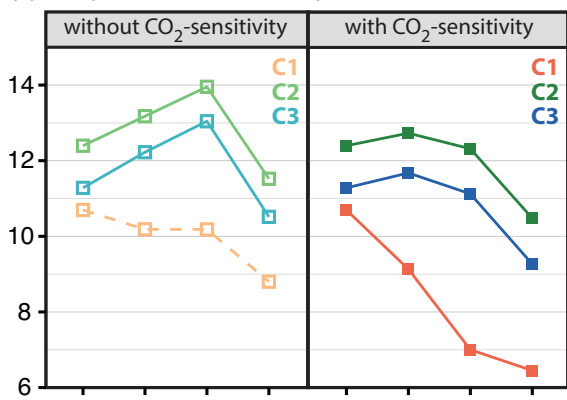

c) $\mathrm{H}_{2} \mathrm{O}_{2}$ (ppbv)

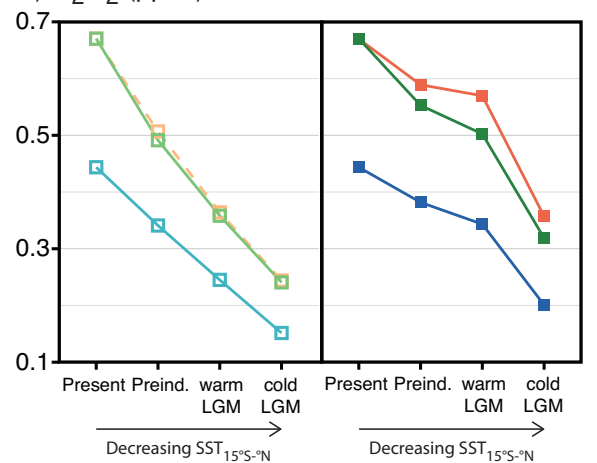

(b) $\mathrm{O}_{3}$ (ppbv)

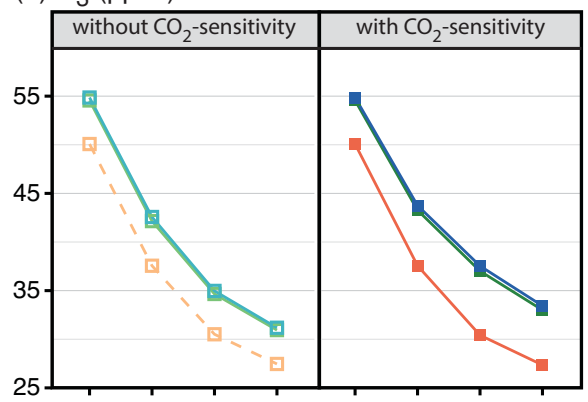

d) $\mathrm{NO}_{3}$ (pptv)

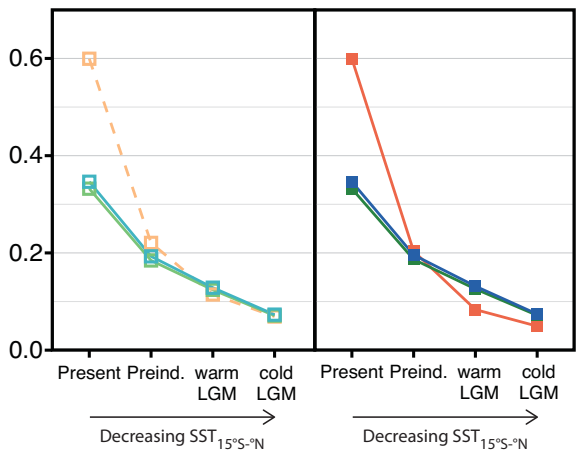

Figure 2. Simulated sensitivity of the tropospheric mean mass-weighted oxidant burdens of $\mathrm{OH}, \mathrm{O}_{3}, \mathrm{H}_{2} \mathrm{O}_{2}$, and $\mathrm{NO}_{3}$ to each combination of climate, chemistry, and plant isoprene emission scheme. Simulations are as described in Table 2. The climate scenarios are present day,

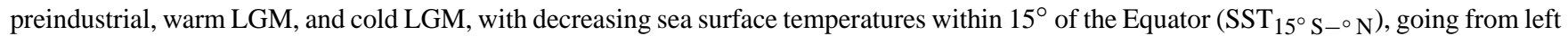
to right along the abscissa. The chemistry schemes are $\mathrm{C} 1$ (orange curves), $\mathrm{C} 2$ (green), and $\mathrm{C} 3$ (blue). Plant isoprene emissions are modeled without (light shaded) or with (dark shaded) sensitivity to atmospheric $\mathrm{CO}_{2}$ concentrations. The tropospheric burdens are calculated with the tropopause determined from the thermal lapse rate. The dotted light-orange line represents the results reported in Murray et al. (2014) for their "best estimate" lightning and fire emissions scenarios.

mean values are $1743 \mathrm{ppbv}$ for the present day, $732 \mathrm{ppbv}$ for the preindustrial, and 377 ppbv for the LGM scenarios.

\section{Results}

\subsection{Tropospheric mean oxidant burdens}

Figure 2 shows the simulated tropospheric mean massweighted burdens of $\mathrm{OH}$, ozone, $\mathrm{H}_{2} \mathrm{O}_{2}$, and $\mathrm{NO}_{3}$ for each combination of climate, chemistry, and plant isoprene emission scenarios. The dotted orange line represents results using the "best estimate" lightning and fire emission scenarios of Murray et al. (2014). The plots show the varying sensitivity of oxidant levels to assumptions about the tropospheric chemical mechanism and the global isoprene burden.

Consideration of the $\mathrm{CO}_{2}$ sensitivity of plant isoprene emissions yields larger isoprene emissions for the preindustrial and LGM scenarios (Table 1). For a given chemistry scheme and climate scenario, this leads to a decrease in the tropospheric mean $\mathrm{OH}$ burden, an increase in $\mathrm{H}_{2} \mathrm{O}_{2}$, and small changes in ozone and $\mathrm{NO}_{3}$. This result can be understood by considering the classical tropospheric ozone- $\mathrm{HO}_{x}-$
$\mathrm{NO}_{x}-\mathrm{CO}$ catalytic cycle (e.g., Rohrer et al., 2014, Fig. 1). In general, daytime oxidation of VOC by reaction with $\mathrm{OH}$ leads to formation of oxidized organic products and $\mathrm{HO}_{2}$. Efficient $\mathrm{HO}_{x}$-cycling depends on the presence of $\mathrm{NO}_{x}$. Since low- $\mathrm{NO}_{x}$ conditions prevail in past atmospheres, an increased isoprene burden represents a net $\mathrm{OH}$ sink but an $\mathrm{HO}_{2}$ source. The self-reaction of $\mathrm{HO}_{2}$ leads to $\mathrm{H}_{2} \mathrm{O}_{2}$ formation. Under low- $\mathrm{NO}_{x}$ conditions, tropospheric ozone production is relatively insensitive to changes in the reactive carbon burden. The tropospheric $\mathrm{NO}_{3}$ burden also shows little change since the abundances of its precursors $\left(\mathrm{NO}_{2}+\mathrm{O}_{3}\right)$ hardly vary with the global isoprene burden.

Implementation of the new isoprene oxidation mechanism leads to large changes in tropospheric oxidant burdens of $\mathrm{OH}$ and $\mathrm{O}_{3}$, but not $\mathrm{H}_{2} \mathrm{O}_{2}$ and $\mathrm{NO}_{3}$, for the past atmospheres. For a given climate scenario, the largest source of uncertainties in global mean $\mathrm{OH}$ arises from differences between the original and new isoprene photo-oxidation mechanisms. Increases in the tropospheric mean $\mathrm{OH}$ burdens result from greater $\mathrm{HO}_{x^{-}}$ regeneration in the new isoprene photo-oxidation cascade (Mao et al., 2013b). The ozone production efficiency - the number of ozone molecules produced per molecule of $\mathrm{NO}_{x}$ consumed (Liu et al., 1987) - is greater in the new isoprene 
Table 1. Atmospheric $\mathrm{CO}_{2}$ concentrations and global annual terrestrial plant isoprene emissions for each climate scenario.

\begin{tabular}{lcccc}
\hline Climate scenario & $\begin{array}{c}{\left[\mathrm{CO}_{2}\right]} \\
(\mathrm{ppmv})\end{array}$ & \multicolumn{2}{c}{$\begin{array}{c}\text { Global annual terrestrial } \\
\text { plant isoprene emissions }\end{array}$} & $\begin{array}{c}\text { Percent change in global isoprene emissions with } \mathrm{CO}_{2} \\
\text { sensitivity relative to without }(\%)\end{array}$ \\
\cline { 3 - 4 } & & $\begin{array}{c}\text { without } \\
\mathrm{CO}_{2} \text { sensitivity } \\
\left(\mathrm{Tg} \mathrm{Cyr}^{-1}\right)\end{array}$ & $\begin{array}{c}\mathrm{CO}_{2} \text { sensith }^{*} \\
\left(\mathrm{Tg} \mathrm{Cyr}^{-1}\right)\end{array}$ & +3.9 \\
\hline Present day & 354 & 536 & 557 & +28 \\
Preindustrial & 280 & 580 & 740 & +78 \\
Warm LGM & 188 & 478 & 849 & +77 \\
Cold LGM & 188 & 261 & 463 & \\
\hline
\end{tabular}

* This study uses the empirical relationship from Possell and Hewitt (2011) to test the sensitivity of plant isoprene emissions to atmospheric $\mathrm{CO}_{2}$ concentrations.

mechanism, leading to increases in the tropospheric ozone burdens. This is because the newly added reactions of recycling of isoprene nitrates, formed in the $\left(\mathrm{ISOPO}_{2}+\mathrm{NO}\right) \mathrm{re}-$ action pathway, can lead to $\mathrm{NO}_{x}$-regeneration, thereby representing a less permanent $\mathrm{NO}_{x}$ sink than nitric acid (Paulot et al., 2012). The present-day burden of $\mathrm{NO}_{3}$ shows a large decrease in response to the new isoprene oxidation scheme, while those of the past atmospheres show little change. The muted $\mathrm{NO}_{3}$ response for the past atmospheres is due to two competing effects in the new scheme: (1) an increased aerosol reactive uptake coefficient of $\mathrm{NO}_{3}$ radicals (from $10^{-4}$ to 0.1 ) leading to greater $\mathrm{NO}_{3}$ depletion (Mao et al., 2013b) and (2) increased abundances in both $\mathrm{NO}_{3}$ precursors $\left(\mathrm{NO}_{2}+\mathrm{O}_{3}\right)$ enhancing its formation. The latter effect is due to greater $\mathrm{NO}_{x}$-recycling and regeneration in the new scheme through isoprene nitrate recycling and hence greater ozone production efficiency and increased lifetime of $\mathrm{NO}_{x}$ reservoir species. For the present day, the increased abundances of $\mathrm{NO}_{3}$ precursors are smaller than those of the past atmospheres. Finally, implementation of the new scheme of $\mathrm{HO}_{2}$ uptake by aerosols leads to significant decreases in the tropospheric mean $\mathrm{OH}$ and $\mathrm{H}_{2} \mathrm{O}_{2}$ burdens in all simulations. This is due to both the higher efficacy of uptake than previously assumed and the formation of $\mathrm{H}_{2} \mathrm{O}$ instead of $\mathrm{H}_{2} \mathrm{O}_{2}$ as a by-product of the uptake, yielding a more efficient $\mathrm{HO}_{x}$ removal pathway.

Despite uncertainties in the isoprene emissions and photochemistry, we find reduced levels of ozone, $\mathrm{H}_{2} \mathrm{O}_{2}$, and $\mathrm{NO}_{3}$ in each combination of chemistry and isoprene emission scenarios for the past atmospheres relative to the present day, a result consistent with Murray et al. (2014). However, their conclusion that $\mathrm{OH}$ is relatively well buffered on glacialinterglacial timescales relative to other tropospheric oxidants does not hold for some of the uncertainties explored in this study. Figure 3 shows the simulated percent changes in the tropospheric mean $\mathrm{OH}$ burden for the present day, warm LGM, and cold LGM scenarios, relative to their respective preindustrial scenarios (e.g., $\mathrm{C} 1-\mathrm{w}$ present day relative to $\mathrm{C} 1-\mathrm{w}$ preindustrial). Consideration of the $\mathrm{CO}_{2}$ sensitivity of plant isoprene emissions alone (C1-w) leads to 23 and $29 \%$

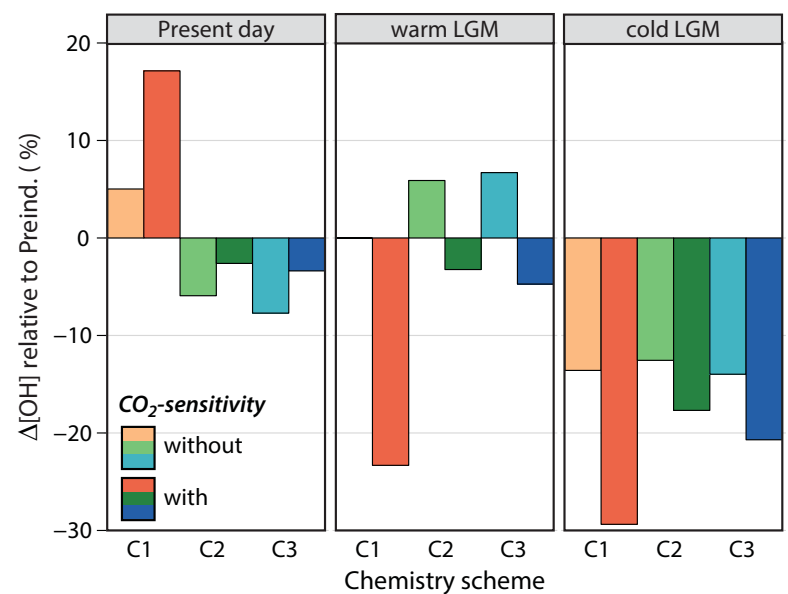

Figure 3. Percent changes (\%) in the tropospheric mean massweighted $\mathrm{OH}$ burden for a range of scenarios relative to their respective preindustrial scenarios (e.g., $\mathrm{C} 1-\mathrm{w}$ present day relative to $\mathrm{C} 1-\mathrm{w}$ preindustrial). Simulations are as described in Table 2 . The climate scenarios are present day, preindustrial, warm LGM, and cold LGM. The chemistry schemes are C1 (orange bars), C2 (green), and C3 (blue). Plant isoprene emissions are modeled without (light shaded) or with (dark shaded) sensitivity to atmospheric $\mathrm{CO}_{2}$ concentrations. For the present day, test simulations with and without $\mathrm{CO}_{2}$ sensitivity yield nearly identical isoprene emissions. We therefore perform all present-day simulations with $\mathrm{CO}_{2}$ sensitivity turned on and assume that these model results apply to the respective presentday "without" scenarios. (Note: The percent change at the warm LGM relative to the preindustrial is very small when the $\mathrm{C} 1$ chemistry scheme is used without consideration of the $\mathrm{CO}_{2}$ sensitivity (C1-wo), and so no light-orange bar is apparent in the middle panel.)

reductions in the tropospheric mean $\mathrm{OH}$ burden in the warm and cold LGM scenarios relative to that of the preindustrial, while the present-day burden is $17 \%$ greater than that of the preindustrial. When the new chemistry schemes are applied without consideration of the $\mathrm{CO}_{2}$ sensitivity, the modeled changes in $\mathrm{OH}$ relative to the preindustrial are less dramatic but have opposite signs to those calculated under the $\mathrm{C} 1-\mathrm{w}$ scenarios for the present day and warm LGM. When 
Table 2. Summary of the different climate, chemistry, and plant isoprene emission scenarios tested in this model study. For each climate scenario except for the present day, all possible combinations of chemistry and emission schemes are tested (for the present day, only the "with" $\mathrm{CO}_{2}$ sensitivity scheme is used). We perform 21 simulations in total.

\begin{tabular}{|c|c|}
\hline Climate & Notes \\
\hline Present day & ca. $1990 \mathrm{~s}$ \\
\hline Preindustrial & ca. $1770 \mathrm{~s}$ \\
\hline Warm LGM & 19-23 ka; SSTs from CLIMAP Project Members (1967) with $\Delta \mathrm{SST}_{15^{\circ} \mathrm{S}-{ }^{\circ} \mathrm{N}}^{\mathrm{a}}$ of $-1.2^{\circ} \mathrm{C}$ \\
\hline Cold LGM & $19-23 \mathrm{ka}$; SSTs from Webb et al. (1997) with $\Delta \mathrm{SST}_{15^{\circ} \mathrm{S}-{ }^{\circ} \mathrm{N}}^{\mathrm{a}}$ of $-6.1^{\circ} \mathrm{C}$ \\
\hline Chemistry & Notes (color scheme used in figures) \\
\hline $\mathrm{C} 1^{\mathrm{b}}$ & Original isoprene chemistry and original $\mathrm{HO}_{2}$ uptake (orange) \\
\hline $\mathrm{C} 2$ & New isoprene chemistry and original $\mathrm{HO}_{2}$ uptake (green) \\
\hline $\mathrm{C} 3$ & New isoprene chemistry and new $\mathrm{HO}_{2}$ uptake (blue) \\
\hline $\mathrm{CO}_{2}$ sensitivity of plant isoprene emission & Notes \\
\hline Without (wo) ${ }^{b}$ & Controlling factors include temperature, light availability, leaf age, and leaf area index \\
\hline With (w) & Controlling factors include the above and atmospheric $\mathrm{CO}_{2}$ concentrations \\
\hline
\end{tabular}

a The average change in sea surface temperature (SST) within $15^{\circ}$ of the Equator relative to the preindustrial.

b The "C1-wo" combination corresponds to the schemes used by Murray et al. (2014) in their "best estimate" scenarios.

all effects are considered (C2-w and $\mathrm{C} 3-\mathrm{w})$, changes in the tropospheric mean $\mathrm{OH}$ burden across the warm LGM-topreindustrial and preindustrial-to-present-day transitions do not exceed 5\%, a result consistent with Murray et al. (2014). The varying sensitivity of the tropospheric mean $\mathrm{OH}$ burden to assumptions about the isoprene photochemistry and emissions has implications for our understanding of past methane and SOA burdens and radiative forcing calculations, as discussed in Sect. 3.3 and 3.4.

\subsection{Comparison with observations}

We evaluate the results of the model sensitivity experiments against four different categories of observations. First, Table 3 compares the simulated methyl chloroform $\left(\mathrm{CH}_{3} \mathrm{CCl}_{3}\right)$ and methane lifetimes against loss from tropospheric $\mathrm{OH}$ under different chemistry schemes with observations for the present day. The global lifetimes of methyl chloroform and of methane against oxidation by tropospheric $\mathrm{OH}$ are calculated as the global burden divided by the total loss rate summed over all grid boxes in the troposphere:

$$
\tau_{X, \mathrm{OH}}=\frac{\int_{\text {surface }}^{\mathrm{TOA}}[X] \mathrm{d} x \mathrm{~d} y \mathrm{~d} z}{\int_{\text {surface }}^{\text {tropopause }} k_{X+\mathrm{OH}}(T)[\mathrm{OH}][X] \mathrm{d} x \mathrm{~d} y \mathrm{~d} z},
$$

where $X$ represents either methyl chloroform or methane, and $k_{X+\mathrm{OH}}(T)$ is the temperature-dependent rate constant of the reaction. We assume that the mixing ratio of methyl chloroform is uniform throughout the troposphere and is $92 \%$ lower than the total atmospheric concentration (Bey et al., 2001; Prather et al., 2012). For methane, the global burden is calculated from the mean surface concentration us-
Table 3. Calculated present-day methyl chloroform $(\mathrm{MCF})$ and methane lifetimes against tropospheric oxidation by $\mathrm{OH}\left(\tau_{\mathrm{MCF}, \mathrm{OH}}\right.$, $\tau_{\mathrm{CH}_{4}, \mathrm{OH}}$ ), with consideration of $\mathrm{CO}_{2}$ sensitivity of plant isoprene emissions.

\begin{tabular}{|c|c|c|c|c|}
\hline \multirow[t]{2}{*}{ Lifetime } & \multicolumn{3}{|c|}{$\begin{array}{l}\text { Calculated from different } \\
\text { model chemistry schemes }\end{array}$} & \multirow[t]{2}{*}{$\begin{array}{l}\text { Inferred from } \\
\text { observations }\end{array}$} \\
\hline & $\mathrm{C} 1$ & $\mathrm{C} 2$ & $\mathrm{C} 3$ & \\
\hline$\tau_{\mathrm{MCF}, \mathrm{OH}}$ (years) & 4.8 & 4.1 & 4.5 & $6.0_{-0.4}^{+0.5 b}$ \\
\hline$\tau_{\mathrm{CH}_{4}, \mathrm{OH}}$ (years) & 10.3 & 8.9 & 9.6 & $11.2 \pm 1.3^{c}$ \\
\hline
\end{tabular}

ing a conversion factor of $2.75 \mathrm{TgCH}_{4} \mathrm{ppbv}^{-1}$ from Prather et al. (2012). In our present-day simulations (ca. 1990s), we prescribe the mean surface concentration as $1743 \mathrm{ppbv}$.

The combination of new isoprene and original $\mathrm{HO}_{2}$ uptake chemistry $(\mathrm{C} 2)$ has the largest simulated tropospheric mean $\mathrm{OH}$ burden (Fig. 2) and so yields the shortest methyl chloroform and methane lifetimes: 4.1 and 8.9 years, respectively. Prinn et al. (2005) inferred an average methyl chloroform lifetime of $6.0_{-0.4}^{+0.5}$ years for the years 1978-2004 based on observations of methyl chloroform and knowledge of its emissions. Our present-day model results range between 4.1 and 4.8 years, which are all lower than the range derived from observations but comparable to recent multi-model estimates of $5.7 \pm 0.9$ years for 2000 (Naik et al., 2013). Based on observations and emission estimates, the mean methane lifetime against loss from tropospheric $\mathrm{OH}$ is estimated to be $10.2_{-0.7}^{+0.9}$ years between 1978 and 2004 by Prinn et al. (2005) and to be $11.2 \pm 1.3$ years for 2010 by Prather 
et al. (2012). The values given by the $\mathrm{C} 1$ (10.3 years) and C3 (9.6 years) chemistry schemes fall within these ranges. The lowest value given by $\mathrm{C} 2$ ( 8.9 years) does not fall within the ranges derived from observations but is still within the range of estimates reported by recent multi-model studies: $10.2 \pm 1.7$ years (Fiore et al., 2009), $9.8 \pm 1.6$ years (Voulgarakis et al., 2013), and $9.7 \pm 1.5$ years (Naik et al., 2013). Reconciling the magnitude of the inferred $\mathrm{OH}$ burden with modeled results remains an ongoing challenge (Holmes et al., 2013).

Second, we also assess our model results for presentday $\mathrm{OH}$ by evaluating the simulated inter-hemispheric ratios $(\mathrm{N} / \mathrm{S})$ of tropospheric mean $\mathrm{OH}$. Estimates of this ratio based on methyl chloroform measurements from 1980 to 2000 range between 0.85 and 0.98 (Montzka et al., 2000; Prinn et al., 2001; Krol and Lelieveld, 2003; Bousquet et al., 2005), whereas the recent ACCMIP multi-model study finds a mean ratio of $1.28 \pm 0.10$ for 2000 (Naik et al., 2013). In our present-day sensitivity experiments, we calculate ratios of 1.20 for $\mathrm{C} 1,1.11$ for $\mathrm{C} 2$, and 1.07 for $\mathrm{C} 3$. The $\mathrm{C} 1$ value falls within the ACCMIP range, but the $\mathrm{C} 3$ value best matches the ratio inferred from observations. Models participating in the ACCMIP study did not consider $\mathrm{HO}_{x}$-recycling pathways under low- $\mathrm{NO}_{x}$ condiions through reactions of peroxy and $\mathrm{HO}_{2}$ radicals (Naik et al., 2013). As previously described, $\mathrm{HO}_{x}$-recycling in the absence of $\mathrm{NO}_{x}$ can occur in our new isoprene photochemistry scheme $(\mathrm{C} 2)$, which leads to a lower present-day $\mathrm{N} / \mathrm{S}$ ratio of tropospheric mean $\mathrm{OH}$. The ratio decreases further and becomes more comparable with the observations when the upper limit of efficacy of $\mathrm{HO}_{2}$ uptake by aerosols is also considered (C3). This result is due to the large anthropogenic aerosol loadings in the Northern Hemisphere.

Third, we compare modeled CO for the preindustrial and present-day simulations against observed $\mathrm{CO}$ surface concentrations over Antarctica (Fig. 4). CO influences the oxidative capacity of the troposphere through reaction with its primary sink, $\mathrm{OH}$, which can subsequently affect the ozone budget (Fiore et al., 2012). In this context, CO can thus be a useful tool for evaluating the ability of chemistry transport models to simulate the tropospheric oxidative capacity (Haan and Raynaud, 1998). CO has a tropospheric lifetime of $\sim 2$ months (Novelli et al., 1998), and CO surface concentrations over Antarctica are thus influenced by oxidation processes throughout much of the Southern Hemisphere (Haan and Raynaud, 1998; van der Werf et al., 2013). The NOAA Global Monitoring Division measured a mean CO surface concentration of $49 \pm 2 \mathrm{ppbv}$ for the 1990s, which is matched by all of our present-day simulations tested with different chemistry schemes. Wang et al. (2010) recently provided a 650-year Antarctic ice-core record of concentration and isotopic ratios of atmospheric CO. They measured CO surface concentrations at the South Pole of $48 \pm 4$ ppbv for the year 1777 ( \pm 110 years). Only one (C1-w) out of the six preindustrial simulations tested with different chemistry and

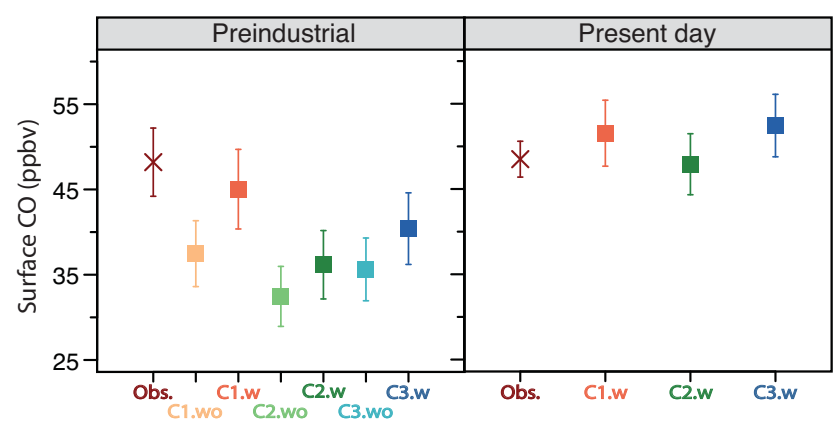

Figure 4. Comparison of model results with observations of $\mathrm{CO}$ surface concentrations (ppbv) over Antarctica for the preindustrial (1770s) and present-day (1990s) simulations. The maroon crosses represent observations from different sources for each time slice. Wang et al. (2010) measured ice-core CO concentrations at the South Pole of $48 \pm 4$ ppbv for the year 1777 ( \pm 110 years); the associated errors represent analytical uncertainties. The mean $\mathrm{CO}$ surface concentration measured at the South Pole by the NOAA Global Monitoring Division for the 1990 s is $49 \pm 2$ ppbv; the associated errors represent interannual variability. The squares represent values averaged over Antarctica from our model simulations tested with different chemistry and isoprene emission schemes for the preindustrial and present-day scenarios. Simulations are as described in Table 2; colors are as in Fig. 2. Error bars associated with the model results represent \pm 1 standard deviation of the spatially averaged mean value.

isoprene emission schemes falls within the range of the observed value. However, in situ production of $\mathrm{CO}$ from organic substrates trapped within the ice may complicate the comparison between ice-core $\mathrm{CO}$ and preindustrial model results (Faïn et al., 2014; Guzmán et al., 2007; Haan and Raynaud, 1998).

Finally, we compare our preindustrial and LGM model results to isotopic signatures in the ice-core record. Oxidants transfer unique isotopic signatures to the oxidation products, and we can take advantage of these signatures in our model evaluation if they are preserved in the icecore record. The $\Delta^{17} \mathrm{O}\left(=\delta^{17} \mathrm{O}-0.52 \times \delta^{18} \mathrm{O}\right)$ of sulfate, known as $\Delta^{17} \mathrm{O}\left(\mathrm{SO}_{4}^{2-}\right)$, and of nitrate, $\Delta^{17} \mathrm{O}\left(\mathrm{NO}_{3}^{-}\right)$, measure the departure from mass-dependent fractionation in its oxygen isotopes and reflect the relative importance of different oxidants in their atmospheric production pathways (Savarino et al., 2000). Sulfate formation primarily involves ozone, $\mathrm{H}_{2} \mathrm{O}_{2}$, and $\mathrm{OH}$, while the main oxidants relevant to nitrate formation are ozone, $\mathrm{RO}_{2}(\mathrm{R}=\mathrm{H}$ atom or organic group), $\mathrm{OH}$, and $\mathrm{BrO}$ (Sofen et al., 2014). Such oxygen triple-isotope measurements have been used to infer the atmospheric formation pathways of sulfate and nitrate in the present from atmospheric sulfate and nitrate (e.g., Lee et al., 2001; Michalski, 2003) and in the past from ice-core sulfate and nitrate (e.g., Alexander et al., 2002, 2004). The dominant source region for Antarctic sulfate is the Southern Ocean marine boundary layer (MBL) (Sofen et al., 2011), 
Table 4. Modeled percent changes in the surface $\left[\mathrm{O}_{3}\right] /[\mathrm{OH}]$ and $\left[\mathrm{O}_{3}\right] /\left[\mathrm{RO}_{2}\right]$ ratios for the present day relative to the preindustrial and in the surface $[\mathrm{OH}]$ concentration for the warm and cold LGM relative to the preindustrial for different model sensitivity experiments. Surface $\left[\mathrm{O}_{3}\right] /[\mathrm{OH}]$ and $[\mathrm{OH}]$ values are averaged over the $46-66^{\circ} \mathrm{S}$ latitude band to compare with values inferred from ice-core measurements of $\Delta^{17} \mathrm{O}\left(\mathrm{SO}_{4}^{2-}\right)$ by Sofen et al. (2014) and Alexander et al. (2002). Surface $\left[\mathrm{O}_{3}\right] /\left[\mathrm{RO}_{2}\right]$ are averaged over $34-54^{\circ} \mathrm{S}$ and $62.5-72.5^{\circ} \mathrm{W}$ (extratropical South America) to compare with values inferred from ice-core measurements of $\Delta^{17} \mathrm{O}\left(\mathrm{NO}_{3}^{-}\right)$by $\mathrm{Sofen}$ et al. $(2014)$, as described in Sect. 3.2.

\begin{tabular}{|c|c|c|c|c|c|}
\hline \multirow{3}{*}{$\begin{array}{l}\text { Chemistry } \\
\text { scheme }^{\mathrm{a}}\end{array}$} & \multirow{3}{*}{$\begin{array}{l}\mathrm{CO}_{2} \text { sensitivity of } \\
\text { plant isoprene emissions }\end{array}$} & \multicolumn{2}{|c|}{ Present-day-preindustrial } & \multirow{2}{*}{$\begin{array}{l}\text { Warm LGM-preindustrial } \\
\text { nt change in surface }\end{array}$} & \multirow{2}{*}{ Cold LGM-preindustrial } \\
\hline & & \multicolumn{2}{|c|}{ Percent change in surface } & & \\
\hline & & $\begin{array}{c}{\left[\mathrm{O}_{3}\right] /[\mathrm{OH}] \text { over }} \\
46-66^{\circ} \mathrm{S}(\%)\end{array}$ & $\begin{array}{r}{\left[\mathrm{O}_{3}\right] /\left[\mathrm{RO}_{2}\right] \text { over }} \\
\text { S. America }(\%)\end{array}$ & $\begin{array}{c}{[\mathrm{OH}] \text { over }} \\
46-66^{\circ} \mathrm{S}(\%)\end{array}$ & $\begin{array}{c}{[\mathrm{OH}] \text { over }} \\
46-66^{\circ} \mathrm{S}(\%)\end{array}$ \\
\hline \multirow[t]{2}{*}{$\mathrm{C} 1$} & without & 35 & 2.3 & 68 & 87 \\
\hline & with & 39 & -0.3 & 105 & 106 \\
\hline \multirow[t]{2}{*}{$\mathrm{C} 2$} & without & 42 & 5.1 & 93 & 95 \\
\hline & with & 42 & 2.8 & 105 & 101 \\
\hline \multirow[t]{2}{*}{$\mathrm{C} 3$} & without & 38 & 2.5 & 102 & 109 \\
\hline & with & 40 & -0.4 & 120 & 117 \\
\hline \multicolumn{2}{|c|}{ Observation-derived estimates } & 260 & -60 to -90 & $40^{b}$ & $40^{\mathrm{b}}$ \\
\hline
\end{tabular}

while that for Antarctic nitrate is extratropical South America (Lee et al., 2014). We thus qualitatively compare our model results for these respective regions with Antarctic ice-core measurements of $\Delta^{17} \mathrm{O}\left(\mathrm{SO}_{4}^{2-}\right)$ and $\Delta^{17} \mathrm{O}\left(\mathrm{NO}_{3}^{-}\right)$.

Table 4 lists the simulated percent changes in surface $\left[\mathrm{O}_{3}\right] /[\mathrm{OH}]$ and $\left[\mathrm{O}_{3}\right] /\left[\mathrm{RO}_{2}\right]$ in the present-day scenarios relative to their respective preindustrial scenarios. Measurements of $\Delta^{17} \mathrm{O}\left(\mathrm{SO}_{4}^{2-}\right)$ from the WAIS Divide ice core imply that the $\left[\mathrm{O}_{3}\right] /[\mathrm{OH}]$ ratio in the Southern Ocean MBL may have increased by $260 \%$ since the early 19 th century. Our model results greatly underestimate the values inferred from observations, with values ranging from 35 to $42 \%$. Measurements of $\Delta^{17} \mathrm{O}\left(\mathrm{NO}_{3}^{-}\right)$suggest that the $\left[\mathrm{O}_{3}\right] /\left[\mathrm{RO}_{2}\right]$ ratio in the southern hemispheric extratropical troposphere may have decreased by $60-90 \%$ between the 1860 s and 2000, assuming no change $(\leq 5 \%)$ in $\mathrm{OH}$ (Sofen et al., 2014). As with the $\left[\mathrm{O}_{3}\right] /[\mathrm{OH}]$ ratio, the model cannot capture the sensitivity of $\left[\mathrm{O}_{3}\right] /\left[\mathrm{RO}_{2}\right]$ to recent climate change, with changes in the ratio ranging from -0.4 to $+5.1 \%$ depending on the scenario. These mismatches may be due to deficiencies in our current understanding and model representation of remote marine boundary layer sulfate formation, as suggested by Sofen et al. (2014), and potential model underestimates of the sensitivity of oxidant abundances to climate change (Alexander and Mickley, 2015).

On glacial-interglacial timescales, measurements of $\Delta^{17} \mathrm{O}\left(\mathrm{SO}_{4}^{2-}\right)$ from the Vostok ice core imply that gas-phase oxidation by $\mathrm{OH}$ contributed up to $40 \%$ more to sulfate production during the last glacial period relative to the interglacial periods before and after (Alexander et al., 2002). Our simulated percent changes in surface $\mathrm{OH}$ concentrations over the Southern Ocean between the LGM and preindustrial scenarios range from 68 to $120 \%$ for the warm LGM and 87 to $117 \%$ for the cold LGM scenarios (Table 4). Given the uncertainties in the model, these values are remarkably consistent with those inferred from the $\Delta^{17} \mathrm{O}\left(\mathrm{SO}_{4}^{2-}\right)$ measurements, both in terms of sign and magnitude.

In summary, we find that all three chemistry schemes yield present-day methyl chloroform lifetimes 24-35\% shorter than that inferred from observations (Prather et al., 2012). For methane, the $\mathrm{C} 1$ and $\mathrm{C} 3$ lifetimes fall within the range inferred from observations (Prinn et al., 2005; Prather et al., 2012), while the $\mathrm{C} 2$ chemistry scheme yields a value $21 \%$ too short compared to the value from Prather et al. (2012). For the $\mathrm{OH} \mathrm{N} / \mathrm{S}$ ratio, the C3 chemistry falls closest to the observations (Montzka et al., 2000; Prinn et al., 2001; Krol and Lelieveld, 2003; Bousquet et al., 2005). Compared to preindustrial ice-core measurements of $\mathrm{CO}$, application of the $\mathrm{C} 1$ scheme with $\mathrm{CO}_{2}$ sensitivity yields the best match, with the other scenarios underestimating $\mathrm{CO}$ by 16-33\%. Slow in situ production of $\mathrm{CO}$ in ice cores may, however, inflate the observed $\mathrm{CO}$ values. Isotopic signatures in sulfate and nitrate provide a means to test the preindustrial and LGM model estimates of the oxidation capacity. For example, for all scenarios we find relatively good agreement of the modeled change in $\mathrm{OH}$ since the LGM compared to that derived from measured $\Delta^{17} \mathrm{O}\left(\mathrm{SO}_{4}^{2-}\right)$. 


\subsection{Implications for the methane budget}

The global methane lifetime against oxidation by tropospheric $\mathrm{OH}, \tau_{\mathrm{CH}_{4}, \mathrm{OH}}$, is calculated as defined by Eq. (1). In GEOS-Chem, atmospheric methane concentrations are prescribed from observations - the tropospheric mean concentrations are $1743 \mathrm{ppbv}$ for the present day, $732 \mathrm{ppbv}$ for the preindustrial, and $377 \mathrm{ppbv}$ for the LGM scenarios (Murray et al., 2014, Table 3). The approximately doubled methane concentration across the LGM-to-preindustrial transition implies an increase in methane emissions, in its lifetime against oxidation, or some combination of both factors.

Table 5 and the left panels of Fig. 5 show the global methane lifetimes against oxidation by tropospheric $\mathrm{OH}$ for each combination of climate, chemistry, and isoprene emission scenarios. In Fig. 5, the dotted orange line represents results using the "best estimate" lightning and fire emission scenarios of Murray et al. (2014). Consideration of the $\mathrm{CO}_{2}$ sensitivity of plant isoprene emissions alone leads to large increases in the past global isoprene emissions, which in turn depress the tropospheric mean $\mathrm{OH}$ burden, thereby lengthening the methane lifetimes by 1.2 years for the preindustrial, 5.3 years for the warm LGM, and 5.9 years for the cold LGM. Conversely, implementation of the new isoprene photo-oxidation scheme leads to larger $\mathrm{OH}$ burdens, resulting in decreases in the methane lifetimes - by 1.4 years for the present day, 2.6 years for the preindustrial, 3.3 years for the warm LGM, and 3.9 years for the cold LGM. Implementation of the new $\mathrm{HO}_{2}$ uptake scheme dampens the $\mathrm{OH}$ burden, which in turn slightly increases the methane lifetimes for each climate scenario.

We compare the sensitivity of changes relative to the preindustrial in the global methane lifetimes and in the implied emissions in the right panels of Fig. 5. The values shown are relative to their respective preindustrial scenarios (e.g., C1$\mathrm{w}$ present day relative to $\mathrm{C} 1-\mathrm{w}$ preindustrial). Results from the "best estimate" scenarios of Murray et al. (2014) suggest that relative to the preindustrial, the global methane lifetime is reduced by 0.7 years in the present and is increased by 0.5 years at the warm LGM. (As discussed in Sect. 2.1, comparison with paleo-observations suggests that their "low-fire, variable-lightning, warm LGM" scenario was the best representation of the LGM atmosphere.) This minimal increase in the lifetime at the LGM puts a higher burden on sources in explaining the glacial-interglacial variability of atmospheric methane concentration. Assuming no large changes occurred in the minor loss mechanisms, methane emissions scale with changes in its loss by $\mathrm{OH}$ in the troposphere (Table 5). As defined in Sect. 3.2, the total loss rate of methane with respect to $\mathrm{OH}$ oxidation in the troposphere $\left(\mathrm{Tg} \mathrm{yr}^{-1}\right)$ is calculated from the integral: $\int_{\text {surface }}^{\text {tropopause }} k_{\mathrm{CH}_{4}+\mathrm{OH}}(T)[\mathrm{OH}]\left[\mathrm{CH}_{4}\right] \mathrm{d} x \mathrm{~d} y \mathrm{~d} z$. For their "best estimate" scenarios, Murray et al. (2014) report that total methane emissions are $150 \%$ higher in the present relative to the preindustrial and are reduced by $50 \%$ at the warm LGM.

Consideration of the $\mathrm{CO}_{2}$ sensitivity of plant isoprene emissions alone results in the global methane lifetime being reduced by 1.9 years in the present and increased by 4.6 years in the warm LGM relative to the respective preindustrial scenario. This result suggests that methane emissions are reduced by $62 \%$ at the warm LGM relative to the preindustrial, which places an even larger burden on sources than in Murray et al. (2014) in explaining the glacialinterglacial variability of atmospheric methane concentration. Implementation of the new isoprene photo-oxidation scheme, either with or without consideration of the $\mathrm{CO}_{2}$ sensitivity of plant isoprene emissions, results in relatively small changes in methane lifetimes across the glacial-interglacial or preindustrial-to-present-day timescales. The resulting estimates of the reductions in methane emissions at the warm LGM relative to the preindustrial (between 46 and $62 \%$ ) are consistent with the Murray et al. (2014) "best estimate" of $50 \%$.

In summary, we find little variability in the implied relative LGM-preindustrial difference in methane emissions with respect to the uncertainties in isoprene photochemistry and emissions tested in this study. However, the range of values derived from the loss of methane by $\mathrm{OH}$ across our sensitivity simulations exceeds the 29-42\% decrease in wetland emissions simulated by the PMIP2 ensemble members (Weber et al., 2010) and the 16 and $23 \%$ decreases in natural methane emissions simulated by Kaplan et al. (2006) and Valdes et al. (2005), respectively.

\subsection{Implications for $\mathrm{SOA}$ and radiative forcing}

Isoprene oxidation products substantially contribute to SOA formation (Henze and Seinfeld, 2006), and so our results have implications for past changes in SOA burdens. Increasingly cooler global temperatures relative to the present day in the preindustrial, warm LGM, and cold LGM scenarios are expected to decrease biogenic isoprene emissions. However, such reductions are dampened or offset when the sensitivity to atmospheric $\mathrm{CO}_{2}$ is also considered, since biogenic isoprene emissions are enhanced at $\mathrm{CO}_{2}$ concentrations below present-day levels. The left panel of Fig. 6 shows the global SOA burdens for each combination of climate, chemistry, and isoprene emission scenarios. The dotted orange line represents results using the "best estimate" lightning and fire emission scenarios of Murray et al. (2014). Consideration of the $\mathrm{CO}_{2}$ sensitivity of plant isoprene emissions alone leads to large increases in the past global isoprene burdens, which subsequently increases SOA at the preindustrial and LGM. For example, when the $\mathrm{CO}_{2}$ sensitivity is considered under the $\mathrm{C} 1$ chemistry scheme (i.e., $\mathrm{C} 1-\mathrm{w}$ compared to $\mathrm{C} 1-w o$ ), the relative increases in the simulated SOA burden are $24 \%$ for the preindustrial, $93 \%$ for the warm LGM, and $80 \%$ for the cold LGM scenarios, as shown in the left panels of Fig. 6. 
Table 5. Global methane burden and lifetime against tropospheric oxidation by $\mathrm{OH}\left(\tau_{\mathrm{CH}_{4}, \mathrm{OH}}\right)$.

\begin{tabular}{|c|c|c|c|c|c|}
\hline Climate & Chemistry & $\mathrm{CO}_{2}$ sensitivity & $\begin{array}{l}\mathrm{CH}_{4} \text { burden } \\
(\mathrm{Tg})^{*}\end{array}$ & $\begin{array}{c}\text { Loss by } \mathrm{OH} \text { in troposphere } \\
\left(\mathrm{Tg} \mathrm{yr}^{-1}\right)\end{array}$ & $\begin{array}{r}{ }^{\tau} \mathrm{CH}_{4}, \mathrm{OH} \\
\text { (years) }\end{array}$ \\
\hline \multirow{3}{*}{ Present day } & $\mathrm{C} 1$ & $\mathrm{w}$ & 4790 & 465 & 10.3 \\
\hline & $\mathrm{C} 2$ & $\mathrm{w}$ & 4790 & 539 & 8.9 \\
\hline & $\mathrm{C} 3$ & $\mathrm{w}$ & 4790 & 497 & 9.6 \\
\hline \multirow{6}{*}{ Preindustrial } & $\mathrm{C} 1$ & wo & 2010 & 184 & 11.0 \\
\hline & & $\mathrm{w}$ & 2010 & 165 & 12.2 \\
\hline & $\mathrm{C} 2$ & wo & 2010 & 238 & 8.4 \\
\hline & & $\mathrm{w}$ & 2010 & 230 & 8.7 \\
\hline & $\mathrm{C} 3$ & wo & 2010 & 223 & 9.0 \\
\hline & & $\mathrm{w}$ & 2010 & 214 & 9.4 \\
\hline \multirow{6}{*}{ Warm LGM } & $\mathrm{C} 1$ & wo & 1040 & 91 & 11.5 \\
\hline & & $\mathrm{w}$ & 1040 & 62 & 16.8 \\
\hline & $\mathrm{C} 2$ & wo & 1040 & 127 & 8.2 \\
\hline & & $\mathrm{w}$ & 1040 & 112 & 9.3 \\
\hline & $\mathrm{C} 3$ & wo & 1040 & 120 & 8.7 \\
\hline & & $\mathrm{w}$ & 1040 & 102 & 10.2 \\
\hline \multirow{6}{*}{ Cold LGM } & $\mathrm{C} 1$ & wo & 1040 & 66 & 15.8 \\
\hline & & $\mathrm{w}$ & 1040 & 48 & 21.7 \\
\hline & $\mathrm{C} 2$ & wo & 1040 & 87 & 11.9 \\
\hline & & $\mathrm{w}$ & 1040 & 79 & 13.1 \\
\hline & $\mathrm{C} 3$ & wo & 1040 & 81 & 12.9 \\
\hline & & $\mathrm{w}$ & 1040 & 72 & 14.5 \\
\hline
\end{tabular}

* Global burden calculated from mean surface concentration using a conversion factor of $2.75 \mathrm{TgCH}_{4} \mathrm{ppbv}^{-1}$ (Prather et al., 2012).

a) Methane lifetimes, $\tau_{\mathrm{CH}_{4}, \mathrm{OH}}$

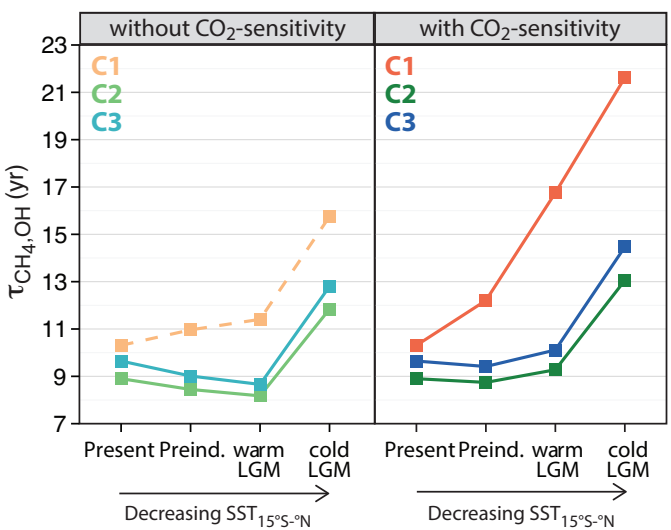

b) Changes relative to the respective preindustrial scenario
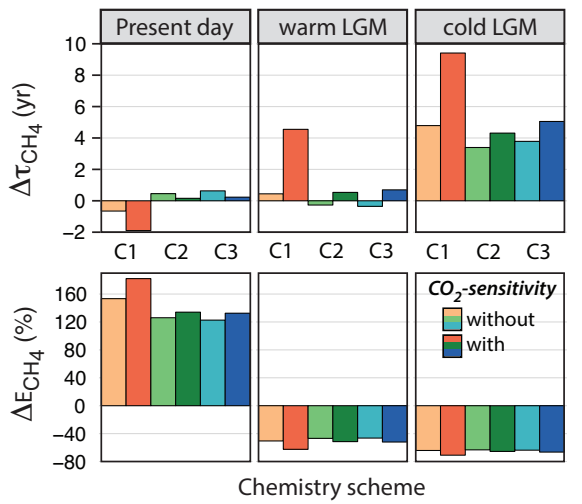

Figure 5. (a) Calculated global methane lifetime against oxidation by tropospheric $\mathrm{OH}$ for each combination of climate, chemistry, and plant isoprene emission scenarios. Simulations are as described in Table 2; colors are as in Fig. 2. The dotted light-orange line represents the results reported in Murray et al. (2014) for their "best estimate" lightning and fire emissions scenarios. (b) Changes in the global methane lifetimes (years) and emissions (\%) relative to their respective preindustrial scenarios (e.g., C1-w present day relative to C1-w preindustrial). Colors are as in Fig. 3. Changes in methane emissions are calculated by assuming that they scale with changes in methane loss by $\mathrm{OH}$ in the troposphere. 
(a) Global SOA burdens

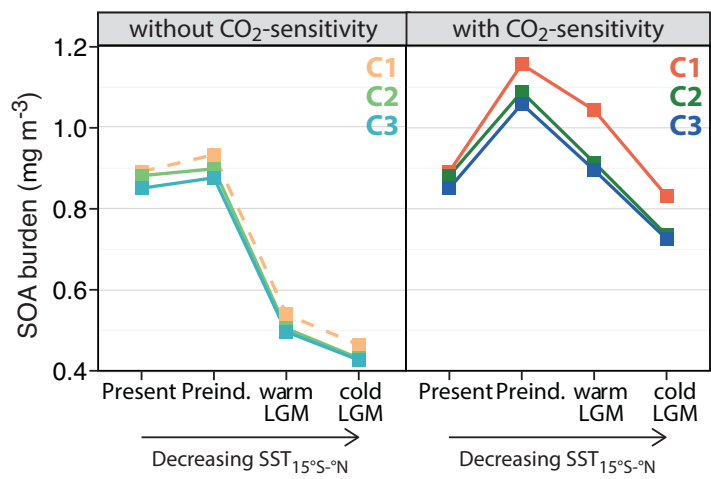

(b) Changes relative to the respective preindustrial scenario

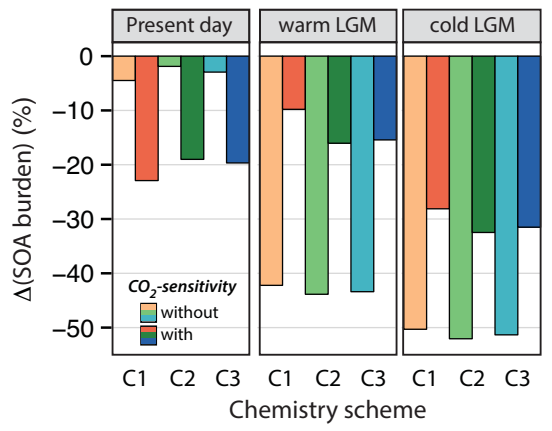

Figure 6. (a) Tropospheric mean mass-weighted secondary organic aerosol (SOA) burdens for each combination of climate, chemistry and plant isoprene emission scenarios. Simulations are as described in Table 2; colors are as in Fig. 2. The dotted light-orange line represents the results reported in Murray et al. (2014) for their "best estimate" lightning and fire emissions scenarios. (b) Percent changes in tropospheric mean SOA burdens relative to their respective preindustrial scenarios (e.g., $\mathrm{C} 1-\mathrm{w}$ present day relative to $\mathrm{C} 1-\mathrm{w}$ preindustrial). Colors are as in Fig. 3.

Conversely, for a given isoprene emission scenario, changes to the isoprene photo-oxidation and $\mathrm{HO}_{2}$ uptake schemes lead to much smaller changes in the SOA burdens in each climate scenario.

The right panel of Fig. 6 shows the percent changes in tropospheric mean SOA burdens relative to their respective preindustrial scenarios (e.g., C1-w present day relative to $\mathrm{C} 1$ w preindustrial). The "best estimate" scenarios of Murray et al. (2014) - represented by our "C1-wo" simulations - suggest that relative to the preindustrial, the total SOA burden is $5 \%$ lower in the present, $42 \%$ lower at the warm LGM, and $50 \%$ lower at the cold LGM. These values, while relatively robust to variations in the isoprene photo-oxidation and $\mathrm{HO}_{2}$ uptake schemes, are sensitive to estimates of the global isoprene burdens for the past atmospheres; consideration of the $\mathrm{CO}_{2}$ sensitivity of plant isoprene emissions enhances the present-to-preindustrial difference but reduces the LGM-to-preindustrial differences in the global SOA burden. For example, under the $\mathrm{C} 1$ chemistry scheme, consideration of the $\mathrm{CO}_{2}$ sensitivity of plant isoprene emissions leads to decreases of $23 \%$ in the total SOA burden in the present, but only of 10 and $28 \%$ in the warm and cold LGM scenarios, relative to the preindustrial.

\subsection{Implications for tropospheric ozone and radiative forcing}

Isoprene and its oxidation products influence the formation and loss of tropospheric ozone (Beerling et al., 2007). As in Murray et al. (2014), we find decreasing tropospheric mean ozone burdens in each progressively colder scenario for each combination of isoprene photochemistry and emissions scenarios. The "best estimate" scenarios of Murray et al. (2014) - represented by our " $\mathrm{C} 1$-wo" simulations - suggest that relative to the preindustrial, the tropospheric mean ozone bur- den is $33 \%$ higher in the present, $27 \%$ lower at the warm LGM, and $19 \%$ lower at the cold LGM. These values do not vary more than $8 \%$ for the present day and $5 \%$ for the LGM when the isoprene photochemistry and/or emission schemes are varied.

Using the multi-model estimate of $0.042 \mathrm{~W} \mathrm{~m}^{-2}$ per DU change in the mean tropospheric column ozone across the preindustrial-present-day transition (Stevenson et al., 2013), we estimate that across our sensitivity simulations, changes in the mean tropospheric column ozone relative to their respective preindustrial scenarios lead to an average forcing contribution of $+0.3 \mathrm{~W} \mathrm{~m}^{-2}$ for the present day. If we extrapolate this relationship to the LGM-preindustrial transition, we estimate values of $-0.3 \mathrm{~W} \mathrm{~m}^{-2}$ for the warm LGM and $-0.2 \mathrm{~W} \mathrm{~m}^{-2}$ for the cold LGM. However, accurate quantification of the tropospheric ozone forcing at the LGM relative to the preindustrial would require the use of an online radiative transfer model that convolves changes in the ozone distribution with other radiatively active climate processes.

\subsection{Factors controlling variability in the tropospheric oxidative capacity}

Murray et al. (2014) identified the key parameters that appear to control global mean $\mathrm{OH}$ levels on glacial-interglacial timescales. In this section, we explore the robustness of their result to the uncertainties in isoprene photochemistry and emissions tested in this study. Using the steadystate equations of the ozone- $\mathrm{NO}_{x}-\mathrm{HO}_{x}-\mathrm{CO}$ system, Wang and Jacob (1998) derived a linear relationship between the global mean $\mathrm{OH}$ burden and the ratio $S_{\mathrm{N}} /\left(S_{\mathrm{C}}^{3 / 2}\right)$, where $S_{\mathrm{N}}$ and $S_{\mathrm{C}}$ are the tropospheric sources of reactive nitrogen $\left(\mathrm{TmolNyr}^{-1}\right)$ and of reactive carbon $\left(\mathrm{TmolC}^{-1}\right)$, respectively. Murray et al. (2014) found that on glacial-interglacial 
timescales, the linear relationship can be maintained if two additional factors, which Wang and Jacob (1998) had assumed constant in their derivation, are also considered: (1) the mean tropospheric ozone photolysis frequency, $J_{\mathrm{O}_{3}}$ $\left(\mathrm{s}^{-1}\right)$, and (2) the tropospheric water vapor concentration, represented by the specific humidity, $q\left(\mathrm{~g} \mathrm{H}_{2} \mathrm{O} \mathrm{kg} \mathrm{air}{ }^{-1}\right)$. In other words,

$[\mathrm{OH}] \propto J_{\mathrm{O}_{3}} q S_{\mathrm{N}} /\left(S_{\mathrm{C}}^{3 / 2}\right)$.

Figure 7 shows a plot of the tropospheric mean $\mathrm{OH}$ burden for each simulation as a function of $J_{\mathrm{O}_{3}} q S_{\mathrm{N}} /\left(S_{\mathrm{C}}^{3 / 2}\right)$, divided into panels according to the chemistry scheme. As in Murray et al. (2014), $S_{\mathrm{C}}$ is calculated as the sum of emissions of $\mathrm{CO}$ and NMVOCs and an implied source of methane equal to its loss rate by $\mathrm{OH}$. While Murray et al. (2014) assumed that each molecule of isoprene yields an average 2.5 carbons that go on to react in the gas phase, this assumption has been found to not be robust for different isoprene oxidation schemes, and so we assume that each isoprene molecule undergoes $100 \%$ gas-phase oxidation for all of the three chemistry schemes tested in this study.

Only the $\mathrm{C} 1$ data subset shows a statistically significant correlation coefficient $(r=0.87, n=7, p<0.01)$; a reduced major axis regression fit is shown by the orange line in Fig. 7. The breakdown in linearity for the $\mathrm{C} 2(r=0.36)$ and $\mathrm{C} 3(r=0.34)$ subsets can by explained by examining the classical tropospheric $\mathrm{NO}_{x}-\mathrm{HO}_{x}-\mathrm{CO}-$ ozone chemistry upon which the linear relationship is derived. In this classical chemistry system, $\mathrm{HO}_{x}$-cycling is coupled to $\mathrm{NO}_{x}$-cycling. However, the new isoprene photo-oxidation mechanism includes additional pathways for $\mathrm{HO}_{x}$-regeneration and recycling in the absence of $\mathrm{NO}_{x}$. The new mechanism thus permits $\mathrm{HO}_{x}$-cycling to occur without subsequent production of ozone through $\mathrm{NO}_{2}$ photolysis, thereby weakening the sensitivity of $\mathrm{OH}$ to each of the individual components of $J_{\mathrm{O}_{3}} q S_{\mathrm{N}} /\left(S_{\mathrm{C}}^{3 / 2}\right)$. For example, Murray et al. (2014) found that the global mean $\mathrm{OH}$ independently varied weakly but most strongly with the photolysis component $\left(J_{\mathrm{O}_{3}}\right)$ in their simulations. In this study, the only subset of simulations exhibiting a statistically significant correlation between $\mathrm{OH}$ and $J_{\mathrm{O}_{3}}$ is $\mathrm{C} 1$-wo $(r=0.98, n=4, p=0.02)$. Note that we are assuming the present-day $\mathrm{C} 1-\mathrm{w}$ simulation to be representative of the C1-wo scenario. This scheme employs the original isoprene and $\mathrm{HO}_{2}$ uptake schemes without consideration of the $\mathrm{CO}_{2}$ sensitivity of plant isoprene emissions - i.e., the same as that used by Murray et al. (2014).

As can be seen by inspection of Fig. 7, the relationship between $\mathrm{OH}$ and $J_{\mathrm{O}_{3}} q S_{\mathrm{N}} /\left(S_{\mathrm{C}}^{3 / 2}\right)$ differs between the LGM-topreindustrial and preindustrial-to-present-day transitions for all of the three data subsets. With the present-day values excluded, we test whether the slope and intercept values are significantly different between the chemistry schemes by fitting a multiple regression model with $J_{\mathrm{O}_{3}} q S_{\mathrm{N}} /\left(S_{\mathrm{C}}^{3 / 2}\right)$ as a

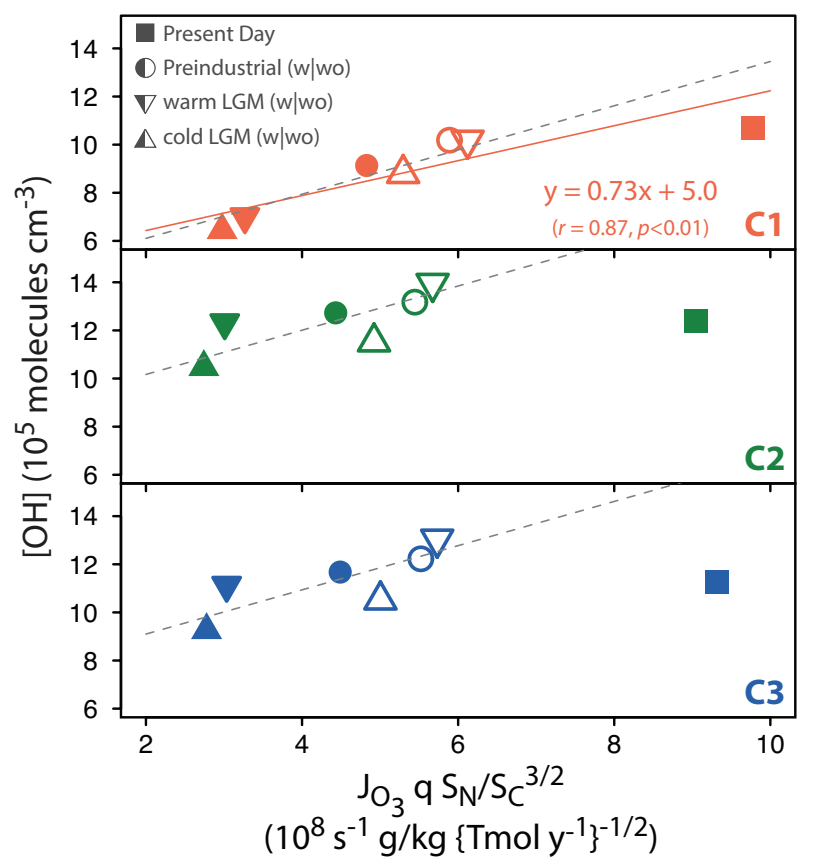

Figure 7. Tropospheric mean mass-weighted $\mathrm{OH}$ burden in each simulation as a function of $J_{\mathrm{O}_{3}} q S_{\mathrm{N}} /\left(S_{\mathrm{C}}^{3 / 2}\right)$, where $J_{\mathrm{O}_{3}}$ is the tropospheric mean mass-weighted ozone photolysis frequency $\left(\mathrm{s}^{-1}\right), q$ is the tropospheric mean mass-weighted specific humidity $\left(\mathrm{g} \mathrm{kg}^{-1}\right)$, and $S_{\mathrm{N}}$ and $S_{\mathrm{C}}$ are the tropospheric sources of reactive nitrogen $\left(\mathrm{Tmol} \mathrm{N} \mathrm{yr}^{-1}\right.$ ) and of reactive carbon $\left(\mathrm{Tmol} \mathrm{Cyr}^{-1}\right)$, respectively. $S_{\mathrm{C}}$ is calculated as the sum of emissions of CO, NMVOCs, and an implied source of methane equal to its loss rate by $\mathrm{OH}$. Model results for different chemistry schemes are separated into three subsets as follows. Top panel: original isoprene chemistry and original $\mathrm{HO}_{2}$ uptake $(\mathrm{C} 1)$. Middle panel: new isoprene chemistry and original $\mathrm{HO}_{2}$ uptake (C2). Bottom panel: new isoprene chemistry and new $\mathrm{HO}_{2}$ uptake (C3). Different symbols denote different climate scenarios (present day, preindustrial, warm LGM, cold LGM). Filled symbols represent simulations in which the $\mathrm{CO}_{2}$ sensitivity of plant isoprene emission is considered (w); unfilled symbols are those without (wo). All present-day simulations were performed with $\mathrm{CO}_{2}$ sensitivity turned on. The orange line shows a reduced major axis regression fit for the $\mathrm{C} 1$ subset, with the regression equation and correlation coefficient $(r=0.87, p<0.01)$ inset. We do not find a statistically significant correlation between $\mathrm{OH}$ and $J_{\mathrm{O}_{3}} q S_{\mathrm{N}} /\left(S_{\mathrm{C}}^{3 / 2}\right)$ for the $\mathrm{C} 2(r=0.36)$ and $\mathrm{C} 3(r=0.34)$ subsets. When the present-day values are excluded and a multiple regression model is fitted to the remaining ensemble, we find that the three different chemistry schemes possess the same values for the slopes of the linear correlation but different values for the intercepts, as shown by the dashed grey lines (see text for details).

continuous explanatory variable and chemistry scheme as a categorical explanatory variable. We find that the three correlations have different values for the intercepts whereas the values for the slopes do not significantly differ (Fig. 7, dashed grey lines). The value of the intercept is largest for the $\mathrm{C} 2 \mathrm{en}-$ semble, followed by $\mathrm{C} 3$ and then $\mathrm{C} 1$. This sequence follows 
from our finding in Fig. 2, described in Sect. 3.1, that the new isoprene photo-oxidation mechanism leads to larger tropospheric mean $\mathrm{OH}$ burdens for each climate scenario compared to those simulated by the original mechanism. Implementation of the new $\mathrm{HO}_{2}$ uptake scheme dampens this increase, but values remain above those from the $\mathrm{C} 1$ ensemble. We postulate two main reasons why the slope of $\mathrm{OH}$ to $J_{\mathrm{O}_{3}} q S_{\mathrm{N}} /\left(S_{\mathrm{C}}^{3 / 2}\right)$ appears to be less steep across the industrial era than across the glacial-interglacial period. First, it is likely that heterogeneous reactions that can also act as $\mathrm{HO}_{x}$ sinks but are not considered in the derivation of the linear relationship, such as $\mathrm{N}_{2} \mathrm{O}_{5}$ hydrolysis and $\mathrm{HO}_{2}$ uptake by aerosols, become more important under present-day conditions. In the present day, tropospheric aerosol mass loading is $17-20 \%$ higher than the preindustrial and $36-52 \%$ higher than the warm and cold LGM scenarios. Second, there is a dramatic shift in the altitudinal distribution of tropospheric $\mathrm{NO}_{x}$ emissions. The ratio of lightning to surface $\mathrm{NO}_{x}$ emissions is 0.16 for the present day, 0.50 for the preindustrial, 0.73 for the warm LGM, and 0.79 for the cold LGM. The much lower present-day ratio is primarily due to large anthropogenic surface $\mathrm{NO}_{x}$ emissions, especially in the Northern Hemisphere (Murray et al., 2014, Fig. 5). This could lead to relatively more efficient $\mathrm{NO}_{x}$ removal by wet and dry deposition and by formation of organic nitrates, which would both reduce primary and secondary $\mathrm{OH}$ production. However, these hypotheses need to be examined in greater detail, and an evaluation of potential weaknesses of the linear relationship between $\mathrm{OH}$ and $J_{\mathrm{O}_{3}} q S_{\mathrm{N}} /\left(S_{\mathrm{C}}^{3 / 2}\right)$ that operate independently of the classic photo-oxidation mechanism is described by Murray et al. (2015).

\section{Discussion and conclusions}

Using a detailed climate-biosphere-chemistry framework, we evaluate the sensitivity of modeled tropospheric oxidant levels to recent advances in our understanding of biogenic isoprene emissions and of the fate of isoprene oxidation products in the atmosphere. We focus on this sensitivity for the present day (ca. 1990s), preindustrial (ca. 1770s), and the LGM ( 19-23 ka). The 3-D global ICECAP model employed here considers the full suite of key factors controlling the oxidative capacity of the troposphere, including the effect of changes in the stratospheric column ozone on tropospheric photolysis rates (Murray et al., 2014). Our study, which revisits Murray et al. (2014), takes into account the sensitivity of plant isoprene emissions to atmospheric $\mathrm{CO}_{2}$ levels and considers the effects of a new isoprene photo-oxidation mechanism (Paulot et al., 2009a, b) and a potentially larger role for heterogeneous $\mathrm{HO}_{2}$ uptake (Mao et al., 2013a). We perform a systematic evaluation of the sensitivity of the chemical composition of past atmospheres to these developments.
We simulate two possible realizations of the LGM, one significantly colder than the other, to bound the range of uncertainty in the extent of tropical cooling at the LGM. For each climate scenario, we test three different chemistry schemes: $\mathrm{C} 1$ uses the original isoprene chemistry and original $\mathrm{HO}_{2}$ uptake, $\mathrm{C} 2$ uses the new isoprene chemistry and original $\mathrm{HO}_{2}$ uptake, and $\mathrm{C} 3$ uses the new isoprene chemistry and new $\mathrm{HO}_{2}$ uptake mechanisms. Each chemistry scheme is tested with or without inclusion of the $\mathrm{CO}_{2}$ sensitivity of biogenic isoprene emissions, except for the present day for which consideration of the $\mathrm{CO}_{2}$ sensitivity results in only a $4 \%$ change in the global isoprene burden. We find that consideration of the $\mathrm{CO}_{2}$ sensitivity of biogenic emissions enhances plant isoprene emissions by $27 \%$ in the preindustrial and by $77-78 \%$ at the LGM relative to respective estimates that do not take into account the $\mathrm{CO}_{2}$ sensitivity. This implementation increases global isoprene emissions in the warm LGM scenario by $15 \%$ relative to the preindustrial. At the LGM, lower sea levels exposed extensive land area in equatorial Asia and Australia, resuling in large regional increases in plant isoprene emissions (Murray et al., 2014, Fig. 7). When we account for the potential increase in biogenic isoprene emissions at low $\mathrm{CO}_{2}$ concentrations, this implementation swamps the effect of cooler temperatures in the warm LGM scenario.

We find that different oxidants have varying sensitivity to the assumptions tested in this study, with $\mathrm{OH}$ being the most sensitive. Although Murray et al. (2014) estimated that $\mathrm{OH}$ is relatively well buffered on glacial-interglacial timescales, we find that this result is not robust to all of the assumptions tested in this study. Across our sensitivity simulations, changes in the global mean $\mathrm{OH}$ levels for the LGM-to-preindustrial transition range between -29 and $+7 \%$ and those for the preindustrial-to-present-day transition range between -8 and $+17 \%$. However, consistent with Murray et al. (2014), we find reduced levels of ozone, $\mathrm{H}_{2} \mathrm{O}_{2}$, and $\mathrm{NO}_{3}$ for the past atmospheres relative to the present day in our ensemble of sensitivity simulations. That study also reported a linear relationship between $\mathrm{OH}$ and tropospheric mean ozone photolysis rates, water vapor, and total emissions of $\mathrm{NO}_{x}$ and reactive carbon $\left(J_{\mathrm{O}_{3}} q S_{\mathrm{N}} /\left(S_{\mathrm{C}}^{3 / 2}\right)\right)$ on LGM-topresent-day timescales. We find that the new isoprene photooxidation mechanism causes a breakdown in this linear relationship across the entire period, as the new mechanism permits $\mathrm{HO}_{x}$-cycling to occur without subsequent production of ozone through $\mathrm{NO}_{2}$ photolysis, thereby weakening the feedback on $\mathrm{OH}$ production per $\mathrm{RO}_{2}$ consumed. We propose that the sensitivity of $\mathrm{OH}$ to changes in $J_{\mathrm{O}_{3}} q S_{\mathrm{N}} /\left(S_{\mathrm{C}}^{3 / 2}\right)$ may be lower for the preindustrial-to-present-day than the LGMto-preindustrial transition. This is most likely because $\mathrm{NO}_{x}$ and $\mathrm{HO}_{x}$ loss processes not considered in the classical $\mathrm{NO}_{x}{ }^{-}$ $\mathrm{HO}_{x}-\mathrm{CO}$-ozone system (from which the linear relationship is derived) become more important under present-day conditions. 
We find little variability in the implied relative LGMpreindustrial difference in methane emissions with respect to the uncertainties in isoprene photochemistry and emissions tested in this study. The resulting estimates of the reductions in methane emissions at the warm LGM relative to the preindustrial (between 46 and $62 \%$ ) are comparable to the Murray et al. (2014) "best estimate" of $50 \%$. However, the range of our implied values exceed those derived from prior model studies of wetland emission changes (Valdes et al., 2005; Kaplan et al., 2006; Weber et al. 2010). Our findings also have implications for radiative forcing estimates of SOA on preindustrial-present and glacial-interglacial timescales. For example, the "best estimate" scenarios of Murray et al. (2014) suggest that relative to the preindustrial, the total SOA burden is $5 \%$ lower in the present and $42 \%$ lower at the LGM. Here, we find decreases ranging between 2 and $23 \%$ in the present and 10 and $44 \%$ at the LGM relative to the preindustrial across our sensitivity experiments. The climate effects of biogenic SOA are not well characterized but are thought to provide regional cooling (Scott et al., 2014). Our work thus suggests that SOA reductions may have amplified regional warming in the present but minimized regional cooling at the LGM relative to the preindustrial. Results from these sensitivity studies, however, underscore the large uncertainties in current model estimates of SOA radiative forcing across long timescales (e.g., Scott et al., 2014; Unger and Yue, 2014; Unger, 2014a). Unlike SOA, we find that changes in tropospheric mean ozone burdens relative to the preindustrial are insensitive to the uncertainties in isoprene emissions and photochemistry tested in this study. Relative to the preindustrial, the absolute magnitude of the radiative forcing from the change in tropospheric ozone at the LGM may be comparable to that of the present day. However, accurate quantification of the tropospheric ozone forcing at the LGM relative to the preindustrial requires the use of an online radiative transfer model that convolves changes in the ozone distribution with other radiatively active climate processes. Nonetheless, most climate simulations of the LGM still use preindustrial ozone values as boundary conditions, including this study and the Paleoclimate Modelling Intercomparison Project 2 (PMIP2; Braconnot et al., 2012).

Besides SOA, changes in biogenic VOC emissions also affect the atmospheric concentrations of other climate forcing agents. Recent studies have demonstrated the importance of considering the net effect of human-induced changes in biogenic VOC emissions on global climate forcing over the industrial period (e.g., Unger, 2014a, b; Heald et al., 2014; Heald and Spracklen, 2015). Unger (2014a) quantified the global radiative impact of changes to the atmospheric concentrations of ozone, methane, and SOA due to a reduction in the emission of biogenic VOCs resulting from global cropland expansion between the 1850s and 2000s. She estimated a net cooling of $-0.11 \pm 0.17 \mathrm{~W} \mathrm{~m}^{-2}$, which is comparable in magnitude but opposite in sign to the net forcing from the changes in surface albedo and land carbon release as- sociated with cropland expansion. When other known anthropogenic influences on biogenic VOC emissions are also considered, the net global climate forcing is estimated to be $-0.17 \mathrm{~W} \mathrm{~m}^{-2}$ (Unger, 2014b). Our work demonstrates that reducing the uncertainties on such an estimate will require improvements in our knowledge of isoprene photochemistry and $\mathrm{CO}_{2}$ sensitivity, as well as reconciling model estimates of land-cover change over the industrial period.

We find that biogenic VOC emissions decrease by $8 \%$ in the present day relative to the preindustrial due to changing meteorology, redistribution of natural vegetation, and cropland expansion and by $25 \%$ when the $\mathrm{CO}_{2}$ sensitivity of isoprene emissions is also considered. The larger reduction is comparable to results from previous studies that have estimated a 20-26\% reduction in biogenic VOC emissions from the late 19th century to the present day (Lathiere et al., 2010; Pacifico et al., 2012; Unger, 2013). Consistent with our study, Lathiere et al. (2010) determined that the $\mathrm{CO}_{2}$ sensitivity effect is the dominant driver of the change in isoprene emissions between 1901 and 2002, with the impact of land-use change about half that of $\mathrm{CO}_{2}$ sensitivity. In contrast, Pacifico et al. (2012) and Unger (2013) found cropland expansion to be the dominant driver of the reduction. This discrepancy likely arises for two reasons. First, our study applied an increase of approximately $10 \%$ in global cropland expansion (Guenther et al., 2012), which is smaller than the $22 \%$ change estimated by Unger (2013). Second, we apply a $\mathrm{CO}_{2}$ sensitivity algorithm that most likely provides an upper limit of this effect for past climates (Possell and Hewitt, 2011).

The primary goal of this model study is to explore the sensitivity of the oxidative capacity of present and past atmospheres to assumptions about isoprene emissions and the fate of its oxidation products. We are reluctant to offer "best guess" estimates in large part because the uncertainty in the $\mathrm{CO}_{2}$-isoprene interaction is substantial and our knowledge of the isoprene photo-oxidation mechanism is still evolving. Some studies have suggested that canopy-scale processes may complement or offset the leaf-scale response to atmospheric $\mathrm{CO}_{2}$ levels (e.g., Sun et al., 2013). Also, it is likely that the application of the same $\mathrm{CO}_{2}$ sensitivity parameterization to all PFTs leads to an overestimate of this effect. As discussed below, observations of the relevant chemical species that could constrain the oxidative capacity of past atmospheres are sparse. Laboratory and field measurements, however, strongly suggest that the $\mathrm{C} 1$ chemistry scheme is an inadequate representation of the isoprene photo-oxidation mechanism (Paulot et al., 2009a, b; Mao et al., 2013b). Therefore, model studies that depend on a simple, C1-like isoprene photo-oxidation scheme are likely outdated, particularly with respect to their ability to accurately simulate the tropospheric oxidative capacity. All of the models participating in the ACCMIP study in support of the IPCC AR5 used a C1-like isoprene photo-oxidation mechanism (Naik et al., 2013). Our results demonstrate that even under identical emission scenarios, the original and new isoprene photo- 
oxidation mechanisms yield different interpretations of various parameters such as changes in global mean $\mathrm{OH}$ and methane lifetime across the preindustrial-present-day transition.

Quantifying the oxidative capacity of past atmospheres remains an ongoing challenge because the oxidants are not directly preserved in the ice-core record, and paleo-proxies that can provide a simple and robust constraint have not been readily identified (Levine et al., 2011a; Alexander and Mickley, 2015). Our results call for greater attention and research efforts in the following measurements to help constrain model estimates of the oxidative capacity of past atmospheres. (1) Ice-core CO: quantifying the amount of $\mathrm{CO}$ produced in situ from organic substrates trapped within the ice would facilitate the use of ice-core $\mathrm{CO}$ measurements as constraints for model results. (2) Ice-core $\Delta^{17} \mathrm{O}\left(\mathrm{NO}_{3}^{-}\right)$: because of its greater sensitivity to oxidant abundances, icecore measurements of $\Delta^{17} \mathrm{O}\left(\mathrm{NO}_{3}^{-}\right)$may in fact provide a more robust proxy than $\Delta^{17} \mathrm{O}\left(\mathrm{SO}_{4}^{2-}\right)$ for reconstructing the oxidation capacity of past atmospheres. For example, cloud amount and $\mathrm{pH}$ do not influence the isotopic composition of nitrate as they do for sulfate (Levine et al., 2011a). In particular, measurements of $\Delta^{17} \mathrm{O}\left(\mathrm{NO}_{3}^{-}\right)$in tropical ice cores, which are so far sparse, may be highly valuable given that the dominant natural sources of $\mathrm{NO}_{x}$ and production of $\mathrm{OH}$ are most prevalent in the tropics (Buffen et al., 2014); (3) field campaigns focused on measurements of oxidant cycling in high-isoprene, low- $\mathrm{NO}_{x}$ environments. Such a suite of observations will help constrain the modeled sensitivity of tropospheric oxidants to past climate changes.

The main scientific value of our study lies in its demonstration of the importance of biogenic VOC emissions and the fate of their oxidation products in influencing chemistryclimate interactions across the last glacial-interglacial time interval and the industrial era. Because of existing uncertainties in isoprene emissions and photochemistry, there are larger uncertainties in model estimates of the oxidative capacity of past atmospheres than previously acknowledged. For example, Levine et al. (2011b) concluded that the effects of temperature and specific humidity cancel out the effects of biogenic NMVOCs on $\mathrm{OH}$ across glacial timescales, with or without consideration of $\mathrm{OH}$-recycling under low- $\mathrm{NO}_{x}$ conditions in the isoprene photo-oxidation mechanism. However, using a more complex tropospheric chemical mechanism, including a more detailed representation of $\mathrm{OH}-$ recycling under low- $\mathrm{NO}_{x}$ conditions, as well as considering the effects of the $\mathrm{CO}_{2}$ sensitivity of plant isoprene emissions and of changes in the stratospheric column ozone and tropospheric $\mathrm{NO}_{x}$ emissions, we demonstrate that uncertainties in the LGM-to-preindustrial change in $\mathrm{OH}$ remain substantial. Such uncertainties, in turn, limit our confidence in estimating radiative forcing due to changes in short-lived species such as SOA over time, as well as our ability to identify the factors controlling global mean OH levels between the LGM and the present day.

Constraining the anthropogenic radiative forcing over the industrial period inherently depends on our ability to quantify the chemical composition of the preindustrial atmosphere. In particular, assessing the radiative forcing from changes involving biogenic processes is an ongoing challenge in the modeling community but has importance in the coming decades as policymakers face decisions that depend critically on accurate knowledge of the atmospheric oxidative capacity. For example, recent studies have demonstrated the importance of considering the net effect of human-induced changes in biogenic VOC emissions on global climate forcing over the industrial period (e.g., Unger, 2014a, b; Heald et al., 2014; Heald and Spracklen, 2015). Tackling the longstanding issue of the dynamics of future global methane sources and sinks is also crucial for the next generation of climate projections (Quiquet et al., 2015; Kirschke et al., 2013). However, including detailed photochemical mechanisms in chemistry-climate models is computationally expensive. In the ACCMIP models involved in the IPCC assessments of the preindustrial and present day, the tropospheric chemical mechanisms of non-methane hydrocarbons were represented in varying degrees of complexity (Lamarque et al., 2013), and the isoprene photo-oxidation mechanisms did not consider $\mathrm{HO}_{x}$-recycling under low- $\mathrm{NO}_{x}$ conditions (Naik et al., 2013). Chemistry-climate models attempting to explain methane trends since the Last Glacial Maximum have also historically depended on relatively simple schemes for isoprene photo-oxidation (e.g., Valdes et al., 2005; Kaplan et al., 2006). Our work points to the value of incorporating into such models both current knowledge and the associated uncertainties regarding biogenic isoprene emissions and photochemistry.

Author contributions. P. Achakulwisut and L. J. Mickley designed the experiments and P. Achakulwisut performed the model simulations and analysis. L. T. Murray, A. P. K. Tai, and J. O. Kaplan developed the model code. P. Achakulwisut prepared the manuscript with contributions from all listed co-authors.

Acknowledgements. The authors would like to thank Mirjam Pfeiffer for performing the LPJ-LMfire simulations, John Mak for providing ice-core CO data, and Daniel Jacob, Karena McKinney, Fabien Paulot, and Malcolm Possell for stimulating discussions. This project was funded by NSF grant AGS-1102880 to Harvard University and to the University of Washington.

Edited by: B. N. Duncan

\section{References}

Alexander, B. and Mickley, L. J.: Paleo-perspectives on potential future changes in the oxidative capacity of the atmosphere due to 
climate change and anthropogenic emissions, Current Pollution Reports, doi:10.1007/s40726-015-0006-0, online first, 2015.

Alexander, B., Savarino, J., Barkov, N. I., Delmas, R. J., and Thiemens, M. H.: Climate driven changes in the oxidation pathways of atmospheric sulfur, Geophys. Res. Lett., 29, 30-1-30-4, doi:10.1029/2002GL014879, 2002.

Alexander, B., Savarino, J., Kreutz, K. J., and Thiemens, M. H.: Impact of preindustrial biomass-burning emissions on the oxidation pathways of tropospheric sulfur and nitrogen, J. Geophys. Res., 109, D08303, doi:10.1029/2003JD004218, 2004.

Bartlein, P. J., Harrison, S. P., Brewer, S., Connor, S., Davis, B. A. S., Gajewski, K., Guiot, J., Harrison-Prentice, T. I., Henderson, A., Peyron, O., Prentice, I. C., Scholze, M., Seppa, H., Shuman, B., Sugita, S., Thompson, R. S., Viau, A. E., Williams, J., and $\mathrm{Wu}, \mathrm{H}$.: Pollenbased continental climate reconstructions at 6 and $21 \mathrm{ka}$ a global synthesis, Clim. Dynam., 37, 775-802, 2011.

Beerling, D. J., Nicholas Hewitt, C., Pyle, J. A., and Raven, J. A.: Critical issues in trace gas biogeochemistry and global change, Philos. T. R. Soc. A, 365, 1629-1642, doi:10.1098/rsta.2007.2037, 2007.

Bey, I., Jacob, D. J., Yantosca, R. M., Logan, J. A., Field, B. D., Fiore, A. M., and Schultz, M. G.: Global modeling of tropospheric chemistry with assimilated meteorology: Model description and evaluation, J. Geophys. Res., 106, 23073, doi:10.1029/2001JD000807, 2001.

Bousquet, P., Hauglustaine, D. A., Peylin, P., Carouge, C., and Ciais, P.: Two decades of $\mathrm{OH}$ variability as inferred by an inversion of atmospheric transport and chemistry of methyl chloroform, Atmos. Chem. Phys., 5, 2635-2656, doi:10.5194/acp-52635-2005, 2005.

Braconnot, P., Harrison, S. P., Kageyama, M., Bartlein, P. J., Masson-Delmotte, V., Abe-Ouchi, A., Otto-Bliesner, B., and Zhao, Y.: Evaluation of climate models using palaeoclimatic data, Nature Climate Change, 2, 417-424, 2012.

Brook, E. J., Harder, S., Severinghaus, J., Steig, E. J., and Sucher, C. M.: On the origin and timing of rapid changes in atmospheric methane during the last glacial period, Global Biogeochem. Cy., 14, 559-572, 2000.

Carslaw, K. S., Lee, L. A., Reddington, C. L., Pringle, K. J., Rap, A., Forster, P. M., Mann, G. W., Spracklen, D. V, Woodhouse, M. T., Regayre, L. A., and Pierce, J. R.: Large contribution of natural aerosols to uncertainty in indirect forcing, Nature, 503, 67-71, doi:10.1038/nature12674, 2013.

CLIMAP Project Members: The Surface of the Ice-Age Earth, Science, 191, 1131-1137, 1976.

de Reus, M., Fischer, H., Sander, R., Gros, V., Kormann, R., Salisbury, G., Van Dingenen, R., Williams, J., Zöllner, M., and Lelieveld, J.: Observations and model calculations of trace gas scavenging in a dense Saharan dust plume during MINATROC, Atmos. Chem. Phys., 5, 1787-1803, doi:10.5194/acp-5-17872005, 2005.

Faïn, X., Chappellaz, J., Rhodes, R. H., Stowasser, C., Blunier, T., McConnell, J. R., Brook, E. J., Preunkert, S., Legrand, M., Debois, T., and Romanini, D.: High resolution measurements of carbon monoxide along a late Holocene Greenland ice core: evidence for in situ production, Clim. Past., 10, 987-1000, doi:10.5194/cp-10-987-2014, 2014.
Fiore, A. M., Dentener, F. J., Wild, O., Cuvelier, C., Schultz, M. G., Hess, P., and Zuber, A.: Multimodel estimates of intercontinental source-receptor relationships for ozone pollution, J. Geophys. Res., 114, D04301, doi:10.1029/2008JD010816, 2009.

Fiore, A. M., Naik, V., Spracklen, D. V, Steiner, A., Unger, N., Prather, M., and Zeng, G.: Global air quality and climate, Chem. Soc. Rev., 41, 6663-6683, doi:10.1039/c2cs35095e, 2012.

Gildor, H., Ashkenazy, Y., Tziperman, E., and Lev, I.: The role of sea ice in the temperatureprecipitation feedback of glacial cycles, Clim. Dynam., 43, 1001-1010, doi:10.1007/s00382- 013-19907, 2014.

Guenther, A., Karl, T., Harley, P., Wiedinmyer, C., Palmer, P. I., and Geron, C.: Estimates of global terrestrial isoprene emissions using MEGAN (Model of Emissions of Gases and Aerosols from Nature), Atmos. Chem. Phys., 6, 3181-3210, doi:10.5194/acp-63181-2006, 2006.

Guenther, A. B., Jiang, X., Heald, C. L., Sakulyanontvittaya, T., Duhl, T., Emmons, L. K., and Wang, X.: The Model of Emissions of Gases and Aerosols from Nature version 2.1 (MEGAN2.1): an extended and updated framework for modeling biogenic emissions, Geosci. Model. Dev., 5, 1471-1492, doi:10.5194/gmd-51471-2012, 2012.

Guilderson, T. P., Fairbanks, R. G., and Rubenstone, J. L.: Tropical Temperature Variations Since 20,000 Years Ago: Modulating Interhemispheric Climate Change, Science, 253, 663-665, doi:10.1126/science.263.5147.663, 1994.

Guzmán, M. I., Hoffmann, M. R., and Colussi, A. J.: Photolysis of pyruvic acid in ice: Possible relevance to $\mathrm{CO}$ and $\mathrm{CO}_{2}$ ice core record anomalies, J. Geophys. Res., 112, D10123, doi:10.1029/2006JD007886, 2007.

Haan, D. and Raynaud, D.: Ice core record of CO variations during the last two millennia: atmospheric implications and chemical interactions within the Greenland ice, Tellus B, 50, 253-262, 1998.

Harder, S. L., Shindell, D. T., Schmidt, G. A., and Brook, E. J.: A global climate model study of $\mathrm{CH}_{4}$ emissions during the Holocene and glacial-interglacial transitions constrained by ice core data, Global Biogeochem. Cy., 21, GB1011, doi:10.1029/2005GB002680, 2007.

Heald, C. L. and Spracklen, D. V.: Land use change impacts on air quality and climate, Chem. Rev., 115, 4476-4496, doi:10.1021/cr500446g, 2015.

Heald, C. L., Ridley, D. A., Kroll, J. H., Barrett, S. R. H., CadyPereira, K. E., Alvarado, M. J., and Holmes, C. H.: Contrasting the direct radiative effect and direct radiative forcing of aerosols, Atmos. Chem. Phys., 14, 5513-5527, doi:10.5194/acp-14-55132014, 2014.

Henze, D. K. and Seinfeld, J. H.: Global secondary organic aerosol from isoprene oxidation, Geophys. Res. Lett., 33, L09812, doi:10.1029/2006GL025976,2006.

Hewitt, C. N., Lee, J. D., MacKenzie, A. R., Barkley, M. P., Carslaw, N., Carver, G. D., Chappell, N. A., Coe, H., Collier, C., Commane, R., Davies, F., Davison, B., DiCarlo, P., Di Marco, C. F., Dorsey, J. R., Edwards, P. M., Evans, M. J., Fowler, D., Furneaux, K. L., Gallagher, M., Guenther, A., Heard, D. E., Helfter, C., Hopkins, J., Ingham, T., Irwin, M., Jones, C., Karunaharan, A., Langford, B., Lewis, A. C., Lim, S. F., MacDonald, S. M., Mahajan, A. S., Malpass, S., McFiggans, G., Mills, G., Misztal, P., Moller, S., Monks, P. S., Nemitz, E., Nicolas-Perea, V., Oetjen, H., Oram, D. E., Palmer, P. I., Phillips, G. J., Pike, R., Plane, 
J. M. C., Pugh, T., Pyle, J. A., Reeves, C. E., Robinson, N. H., Stewart, D., Stone, D., Whalley, L. K., and Yin, X.: Overview: oxidant and particle photochemical processes above a south-east Asian tropical rainforest (the OP3 project): introduction, rationale, location characteristics and tools, Atmos. Chem. Phys., 10, 169-199, doi:10.5194/acp-10-169-2010, 2010.

Hofzumahaus, A., Rohrer, F., Lu, K., Bohn, B., Brauers, T., Chang, C.-C., and Zhang, Y.: Amplified trace gas removal in the troposphere, Science, 324, 1702-1704, doi:10.1126/science.1164566, 2009.

Holden, P. B., Edwards, N. R., Wolff, E. W., Lang, N. J., Singarayer, J. S., Valdes, P. J., and Stocker, T. F.: Interhemispheric coupling, the West Antarctic Ice Sheet and warm Antarctic interglacials, Clim. Past, 6, 431-443, doi:10.5194/cp-6-431-2010, 2010.

Holmes, C. D., Prather, M. J., Søvde, O. A., and Myhre, G.: Future methane, hydroxyl, and their uncertainties: key climate and emission parameters for future predictions, Atmos. Chem. Phys., 13, 285-302, doi:10.5194/acp-13-285-2013, 2013.

Horowitz, L. W., Liang, J., Gardner, G. M., and Jacob, D. J.: Export of reactive nitrogen from North America during summertime: Sensitivity to hydrocarbon chemistry, J. Geophys. Res., 103, 13451-13476, 1998.

Hutterli, M. A., Bales, R. C., Mcconnell, J. R., and Stewart, R. W.: HCHO in Antarctic snow: Preservation in ice cores and air-snow exchange, Geophys. Res. Lett., 29, 1235, doi:10.1029/2001GL014256, 2002.

Isaksen, I. S. and Dalsøren, S. B.: Atmospheric science. Getting a better estimate of an atmospheric radical, Science, 331, 38-39, doi:10.1126/science.1199773, 2011.

Kaplan, J. O.: Wetlands at the Last Glacial Maximum: Distribution and methane emissions, Geophys. Res. Lett., 29, 1079, doi:10.1029/2001GL013366, 2002.

Kaplan, J. O., Folberth, G., and Hauglustaine, D. A.: Role of methane and biogenic volatile organic compound sources in late glacial and Holocene fluctuations of atmospheric methane concentrations, Global Biogeochem. Cy., 20, GB2016, doi:10.1029/2005GB002590, 2006.

Khalil, M. A. K. and Rasmussen, R. A.: Atmospheric methane: Trends over the last 10000 years, Atmos. Environ., 21, 24452452, 1987.

Kirschke, S., Bousquet, P., Ciais, P., Saunois, M., Canadell, J. G., Dlugokencky, E. J., Bergamaschi, P., Bergmann, D., Blake, D. R., Bruhwiler, L., Cameron-Smith, P., Castaldi, S., Chevallier, F., Feng, L., Fraser, A., Heimann, M., Hodson, E. L., Houweling, S., Josse, B., Fraser, P. J., Krummel, P. B., Lamarque, J.-F., Langenfelds, R. L., Le Quere, C., Naik, V., O’Doherty, S., Palmer, P. I., Pison, I., Plummer, D., Poulter, B., Prinn, R. G., Rigby, M., Ringeval, B., Santini, M., Schmidt, M., Shindell, D. T., Simpson, I. J., Spahni, R., Steele, L. P., Strode, S. A., Sudo, K., Szopa, S., van der Werf, G. R., Voulgarakis, A., van Weele, M., Weiss, R. F., Williams, J. E., and Zeng, G.: Three decades of global methane sources and sinks, Nat. Geosci, 6, 813-823, doi:10.1038/ngeo1955, 2013

Krol, M. and Lelieveld, J.: Can the variability in tropospheric $\mathrm{OH}$ be deduced from measurements of 1,1,1-trichloroethane (methyl chloroform)?, J. Geophys. Res., 108, 4125, doi:10.1029/2002JD002423, 2003.

Lamarque, J.-F., Shindell, D. T., Josse, B., Young, P. J., Cionni, I., Eyring, V., Bergmann, D., Cameron-Smith, P., Collins, W. J., Do- herty, R., Dalsoren, S., Faluvegi, G., Folberth, G., Ghan, S. J., Horowitz, L. W., Lee, Y. H., MacKenzie, I. A., Nagashima, T., Naik, V., Plummer, D., Righi, M., Rumbold, S. T., Schulz, M., Skeie, R. B., Stevenson, D. S., Strode, S., Sudo, K., Szopa, S., Voulgarakis, A., and Zeng, G.: The Atmospheric Chemistry and Climate Model Intercomparison Project (ACCMIP): overview and description of models, simulations and climate diagnostics, Geosci. Model Dev., 6, 179-206, doi:10.5194/gmd-6-179-2013, 2013.

Lathière, J., Hauglustaine, D. A., De Noblet-Ducoudré, N., Krinner, G., and Folberth, G. A.: Past and future changes in biogenic volatile organic compound emissions simulated with a global dynamic vegetation model, Geophys. Res. Lett., 32, L20818, doi:10.1029/2005GL024164, 2005.

Lathière, J., Hewitt, C. N., and Beerling, D. J.: Sensitivity of isoprene emissions from the terrestrial biosphere to 20th century changes in atmospheric $\mathrm{CO}_{2}$ concentration, climate, and land use, Global Biogeochem. Cy., 24, GB1004, doi:10.1029/2009GB003548, 2010.

Lee, C. C. W., Savarino, J., and Thiemsen, M. H.: Mass independent oxygen isotopic composition of atmospheric sulfate: Origin and implications for the present and past atmospheres of Earth and Mars, Geophys. Res. Lett., 28, 1783-1786, 2001.

Lee, H.-M., Henze, D. K., Alexander, B., and Murray, L. T.: Investigating the sensitivity of surface-level nitrate seasonality in Antarctica to primary sources using a global model, Atmos. Environ., 89, 757-767, doi:10.1016/j.atmosenv.2014.03.003, 2014.

LeGrande, A. N., Schmidt, G. A., Shindell, D. T., Field, C. V., Miller, R. L., Koch, D. M., and Hoffmann, G.: Consistent simulations of multiple proxy responses to an abrupt climate change event, P. Natl. Acad. Sci. USA, 103, 837-842, 2006.

Lelieveld, J., Butler, T. M., Crowley, J. N., Dillon, T. J., Fischer, H., Ganzeveld, L., and Williams, J.: Atmospheric oxidation capacity sustained by a tropical forest, Nature, 452, 737-740, doi:10.1038/nature06870, 2008.

Levine, J. G., Wolff, E. W., Jones, A. E., Hutterli, M. A., Wild, O., Carver, G. D., and Pyle, J. A.: In search of an ice core signal to differentiate between source-driven and sink-driven changes in atmospheric methane, J. Geophys. Res., 116, D05305, doi:10.1029/2010JD014878, 2011a.

Levine, J. G., Wolff, E. W. , Jones, A. E., Sime, L. C., Valdes, P. J., Archibald, A. T., Carver, G. D., Warwick, N. J., and Pyle, J. A.: Reconciling the Changes in Atmospheric Methane Sources and Sinks between the Last Glacial Maximum and the Pre-Industrial Era, J. Geophys. Res., 38, L23804, doi:10.1029/2011g1049545, $2011 b$.

Liu, S. C., Trainer, M., Fehsenfeld, F. C., Parrish, D. D., Williams, E. J., Fahey, D. W., and Murphy, P. C.: Ozone production in the rural troposphere and the implications for regional and global ozone distributions, J. Geophys. Res., 92, 4191-4207, 1987.

Liu, Y. J., Herdlinger-Blatt, I., McKinney, K. A., and Martin, S. T.: Production of methyl vinyl ketone and methacrolein via the hydroperoxyl pathway of isoprene oxidation, Atmos. Chem. Phys., 13, 5715-5730, doi:10.5194/acp-13-5715-2013, 2013.

Mahowald, N. M., Yoshioka, M., Collins, W. D., Conley, A. J., Fillmore, D. W., and Coleman, D. B.: Climate response and radiative forcing from mineral aerosols during the last glacial maximum, pre-industrial, current and doubled-carbon dioxide climates, 
Geophys. Res. Lett., 33, L20705, doi:10.1029/2006GL026126, 2006.

Mao, J., Jacob, D. J., Evans, M. J., Olson, J. R., Ren, X., Brune, W. H., Clair, J. M. St., Crounse, J. D., Spencer, K. M., Beaver, M. R., Wennberg, P. O., Cubison, M. J., Jimenez, J. L., Fried, A., Weibring, P., Walega, J. G., Hall, S. R., Weinheimer, A. J., Cohen, R. C., Chen, G., Crawford, J. H., McNaughton, C., Clarke, A. D., Jaeglé, L., Fisher, J. A., Yantosca, R. M., Le Sager, P., and Carouge, C.: Chemistry of hydrogen oxide radicals $\left(\mathrm{HO}_{x}\right)$ in the Arctic troposphere in spring, Atmos. Chem. Phys., 10, 58235838, doi:10.5194/acp-10-5823-2010, 2010.

Mao, J., Ren, X., Zhang, L., Van Duin, D. M., Cohen, R. C., Park, J.-H., Goldstein, A. H., Paulot, F., Beaver, M. R., Crounse, J. D., Wennberg, P. O., DiGangi, J. P., Henry, S. B., Keutsch, F. N., Park, C., Schade, G. W., Wolfe, G. M., Thornton, J. A., and Brune, W. H.: Insights into hydroxyl measurements and atmospheric oxidation in a California forest, Atmos. Chem. Phys., 12, 8009-8020, doi:10.5194/acp-12-8009-2012, 2012.

Mao, J., Fan, S., Jacob, D. J., and Travis, K. R.: Radical loss in the atmosphere from $\mathrm{Cu}-\mathrm{Fe}$ redox coupling in aerosols, Atmos. Chem. Phys., 13, 509-519, doi:10.5194/acp-13-509-2013, 2013a.

Mao, J., Paulot, F., Jacob, D. J., Cohen, R. C., Crounse, J. D., Wennberg, P. O., and Horowitz, L. W.: Ozone and organic nitrates over the eastern United States: Sensitivity to isoprene chemistry, J. Geophys. Res.-Atmos., 118, 11256-11268, doi:10.1002/jgrd.50817, 2013 b.

McLinden, C. A., Olsen, S. C., Hannegan, B., Wild, O., and Prather, M. J.: Stratospheric ozone in 3-D models: A simple chemistry and the cross-tropopause flux, J. Geophys. Res., 14653-14665, 2000.

Michalski, G.: First measurements and modeling of $\Delta^{17} \mathrm{O}$ in atmospheric nitrate, Geophys. Res. Lett., 30, 1870, doi:10.1029/2003GL017015, 2003.

Montzka, S. A., Spivakovsky, C. M., Butler, J. H., Elkins, J. W., Lock, L. T., and Mondeel, D. J.: New observational constraints, for atmospheric hydroxyl on global and hemispheric scales, Science, 288, 500-503, 2000.

Murray, L. T., Mickley, L. J., Kaplan, J. O., Sofen, E. D., Pfeiffer, M., and Alexander, B.: Factors controlling variability in the oxidative capacity of the troposphere since the Last Glacial Maximum, Atmos. Chem. Phys., 14, 3589-3622, doi:10.5194/acp-143589-2014, 2014.

Murray, L. T., Fiore, A. M., Shindell, D. T., Naik, V., Horowitz, L. W., and Evans, M. J.: Uncertainties in global atmospheric hydroxyl projections tied to fate of reactive nitrogen and carbon, in preparation, 2015.

Naik, V., Voulgarakis, A., Fiore, A. M., Horowitz, L. W., Lamarque, J.-F., Lin, M., Prather, M. J., Young, P. J., Bergmann, D., Cameron-Smith, P. J., Cionni, I., Collins, W. J., Dalsøren, S. B., Doherty, R., Eyring, V., Faluvegi, G., Folberth, G. A., Josse, B., Lee, Y. H., MacKenzie, I. A., Nagashima, T., van Noije, T. P. C., Plummer, D. A., Righi, M., Rumbold, S. T., Skeie, R., Shindell, D. T., Stevenson, D. S., Strode, S., Sudo, K., Szopa, S., and Zeng, G.: Preindustrial to present-day changes in tropospheric hydroxyl radical and methane lifetime from the Atmospheric Chemistry and Climate Model Intercomparison Project (ACCMIP), Atmos. Chem. Phys., 13, 5277-5298, doi:10.5194/acp-13-5277-2013, 2013.
Novelli, P. C., Masarie, K. A., and Lang, P. M.: Distributions and recent changes of carbon monoxide in the lower troposphere, J. Geophys. Res., 103, 19015-19033, doi:10.1029/98JD01366, 1998.

Oyarzun, R., Lillo, J., Sánchez-Hernández, J. C., and Higueras, P.: Pre-industrial Metal Anomalies in Ice Cores: A Simplified Reassessment of Windborne Soil Dust Contribution and Volcanic Activity during the Last Glaciation, Int. Geol. Rev., 47, 11201130, doi:0.2747/0020-6814.47.11.1120, 2005.

Pacifico, F., Folberth, G. A., Jones, C. D., Harrison, S. P., and Collins, W. J.: Sensitivity of biogenic isoprene emissions to past, present, and future environmental conditions and implications for atmospheric chemistry, J. Geophys. Res., 117, D22303, doi:10.1029/2012JD018276, 2012.

Park, R., Jacob, D. J., Field, B., Yantosca, R., and Chin, M.: Natural and transboundary pollution influences on sulfate-nitrateammonium aerosols in the United States: Implications for policy, J. Geophys. Res., 109, D15204, doi:10.1029/2003JD004473, 2004.

Parrella, J. P., Jacob, D. J., Liang, Q., Zhang, Y., Mickley, L. J., Miller, B., Evans, M. J., Yang, X., Pyle, J. A., Theys, N., and Van Roozendael, M.: Tropospheric bromine chemistry: implications for present and pre-industrial ozone and mercury, Atmos. Chem. Phys., 12, 6723-6740, doi:10.5194/acp-12-67232012, 2012.

Paulot, F., Crounse, J. D., Kjaergaard, H. G., Kroll, J. H., Seinfeld, J. H., and Wennberg, P. O.: Isoprene photooxidation: new insights into the production of acids and organic nitrates, Atmos. Chem. Phys., 9, 1479-1501, doi:10.5194/acp-9-1479-2009, 2009a.

Paulot, F., Crounse, J. D., Kjaergaard, H. G., Kürten, A., Clair, J. M. S., Seinfeld, J. H., and Wennberg, P. O.: Unexpected Epoxide Formation in the Gas-Phase Photooxidation of Isoprene, Science, 325, 730-733, 2009b.

Paulot, F., Henze, D. K., and Wennberg, P. O.: Impact of the isoprene photochemical cascade on tropical ozone, Atmos. Chem. Phys., 12, 1307-1325, doi:10.5194/acp-12-1307-2012, 2012.

Paulot, F., Jacob, D. J., and Henze, D. K.: Sources and Processes Contributing to Nitrogen Deposition: An Adjoint Model Analysis Applied to Biodiversity Hotspots Worldwide, Environ. Sci. Technol., 47, 3226-3233, 2013.

Pavelin, E. G., Johnson, C. E., Rughooputh, S., and Toumi, R.: Evaluation of pre-industrial surface ozone measurements made using Schönbein's method, Atmos. Environ., 33, 919-929, 1999.

Peñuelas, J. and Staudt, M.: BVOCs and global change, Trends Plant Sci., 15, 133-144, doi:10.1016/j.tplants.2009.12.005, 2010.

Pfeiffer, M., Spessa, A., and Kaplan, J. O.: A model for global biomass burning in preindustrial time: LPJ-LMfire (v1.0), Geosci. Model Dev., 6, 643-685, doi:10.5194/gmd-6-643-2013, 2013.

Pike, R. C. and Young, P. J.: How plants can influence tropospheric chemistry?: the role of isoprene emissions from the biosphere, Weather, 64, 332-336, 2009.

Possell, M. and Hewitt, C. N.: Isoprene emissions from plants are mediated by atmospheric $\mathrm{CO}_{2}$ concentrations, Glob. Change Biol., 17, 1595-1610, doi:10.1111/j.1365-2486.2010.02306.x, 2011. 
Power, M. J., Marlon, J., Ortiz, N., Bartlein, P. J., Harrison, S. P., Mayle, F. E., and Zhang, J. H.: Changes in fire regimes since the Last Glacial Maximum: an assessment based on a global synthesis and analysis of charcoal data, Clim. Dynam., 30, 887-907, doi:10.1007/s00382-007-0334-x, 2007.

Power, M. J., Marlon, J. R., Bartlein, P. J., and Harrison, S. P.: Fire history and the Global Charcoal Database: A new tool for hypothesis testing and data exploration, Palaeogeogr. Palaeocl., 291, 52-59, doi:10.1016/j.palaeo.2009.09.014, 2010.

Prather, M. J., Holmes, C. D., and Hsu, J.: Reactive greenhouse gas scenarios: Systematic exploration of uncertainties and the role of atmospheric chemistry, Geophys. Res. Lett., 39, L09803, doi:10.1029/2012GL051440, 2012.

Prinn, R. G., Huang, J., Weiss, R. F., Cunnold, D. M., Fraser, P. J., Simmonds, P. G., McCulloch, A., Harth, C., Salameh, P., O?Doherty, S., Wang, R. H. J., Porter, L., and Miller, B. R.: Evidence for substantial variations of atmospheric hydroxyl radicals over the past two decades, Science, 292, 1882-1888, 2001.

Prinn, R. G., Huang, J., Weiss, R. F., Cunnold, D. M., Fraser, P. J., Simmonds, P. G., and Krummel, P. B.: Evidence for variability of atmospheric hydroxyl radicals over the past quarter century, Geophys. Res. Lett., 32, L07809, doi:10.1029/2004GL022228, 2005.

Quiquet, A., Archibald, A. T., Friend, A. D., Chappellaz, J., Levine, J. G., Stone, E. J., Telford, P. J., and Pyle, J. A.: The relative importance of methane sources and sinks over the Last Interglacial period and into the last glaciation, Quaternary Sci. Rev., 112, 116, doi:10.1016/j.quascirev.2015.01.004, 2015.

Rind, D., Chandler, M., Lonergan, P., and Lerner, J.: Climate change and the middle atmosphere: 5. Paleostratosphere in cold and warm climates, J. Geophys. Res., 106, 20195, doi:10.1029/2000JD900548, 2001.

Rind, D., Lerner, J., McLinden, C., and Perlwitz, J.: Stratospheric ozone during the Last Glacial Maximum, Geophys. Res. Lett., 36, L09712, doi:10.1029/2009GL037617, 2009.

Rohrer, F., Lu, K., Hofzumahaus, A., Bohn, B., Brauers, T., Chang, C.-C., and Wahner, A.: Maximum efficiency in the hydroxylradical-based self-cleansing of the troposphere, Nat. Geosci., 7, 559-563, doi:10.1038/ngeo2199, 2014.

Savarino, J., Lee, C. C. W., and Thiemens, M. H.: Laboratory oxygen isotopic study of sulfur (IV) oxidation: Origin of the massindependent oxygen isotopic anomaly in atmospheric sulfates and sulfate mineral deposits on Earth, J. Geophys. Res., 105, 29079-29088, doi:10.1029/2000JD900456, 2000.

Scott, C. E., Rap, A., Spracklen, D. V., Forster, P. M., Carslaw, K. S., Mann, G. W., Pringle, K. J., Kivekäs, N., Kulmala, M., Lihavainen, H., and Tunved, P.: The direct and indirect radiative effects of biogenic secondary organic aerosol, Atmos. Chem. Phys., 14, 447-470, doi:10.5194/acp-14-447-2014, 2014.

Sitch, S., Cox, P. M., Collins, W. J., and Huntingford, C.: Indirect radiative forcing of climate change through ozone effects on the land-carbon sink, Nature, 448, 791-794, doi:10.1038/nature06059, 2007.

Sofen, E. D., Alexander, B., and Kunasek, S. A.: The impact of anthropogenic emissions on atmospheric sulfate production pathways, oxidants, and ice core $\Delta^{17} \mathrm{O}\left(\mathrm{SO}_{4}^{2-}\right)$, Atmos. Chem. Phys., 11, 3565-3578, doi:10.5194/acp-11-3565-2011, 2011.

Sofen, E. D., Alexander, B., Steig, E. J., Thiemens, M. H., Kunasek, S. A., Amos, H. M., Schauer, A. J., Hastings, M. G., Bautista, J.,
Jackson, T. L., Vogel, L. E., McConnell, J. R., Pasteris, D. R., and Saltzman, E. S.: WAIS Divide ice core suggests sustained changes in the atmospheric formation pathways of sulfate and nitrate since the 19th century in the extratropical Southern Hemisphere, Atmos. Chem. Phys., 14, 5749-5769, doi:10.5194/acp14-5749-2014, 2014.

Spolaor, A., Vallelonga, P., Cozzi, G., Gabrieli, J., Varin, C., Kehrwald, N., Zennaro, P., Boutron, C., and Barbante, C.: Iron speciation in aerosol dust influences iron bioavailability over glacial-interglacial timescales, Geophys. Res. Lett., 40, 1-6, doi:10.1002/grl.50296, 2013.

Stevenson, D. S., Young, P. J., Naik, V., Lamarque, J.-F., Shindell, D. T., Voulgarakis, A., Skeie, R. B., Dalsoren, S. B., Myhre, G., Berntsen, T. K., Folberth, G. A., Rumbold, S. T., Collins, W. J., MacKenzie, I. A., Doherty, R. M., Zeng, G., van Noije, T. P. C., Strunk, A., Bergmann, D., Cameron-Smith, P., Plummer, D. A., Strode, S. A., Horowitz, L., Lee, Y. H., Szopa, S., Sudo, K., Nagashima, T., Josse, B., Cionni, I., Righi, M., Eyring, V., Conley, A., Bowman, K. W., Wild, O., and Archibald, A.: Tropospheric ozone changes, radiative forcing and attribution to emissions in the Atmospheric Chemistry and Climate Model Intercomparison Project (ACCMIP), Atmos. Chem. Phys., 13, 3063-3085, doi:10.5194/acp-13-3063-2013, 2013.

Stute, M., Forster, M., Frischkorn, H., Serejo, A., Clark, J. F., Schlosser, P., Broecker, W. S., and Bonani, G.: Cooling of Tropical Brazil $\left(5^{\circ} \mathrm{C}\right)$ During the Last Glacial Maximum, Science, 269, 379-383, doi:10.1126/science.269.5222.379, 1995.

Sun, Z., Niinemets, Ü., Hüve, K., Rasulov, B., and Noe, S. M.: Elevated atmospheric $\mathrm{CO}_{2}$ concentration leads to increased whole-plant isoprene emission in hybrid aspen (Populus tremula x Populus tremuloides), New Phytol., 198, 788-800, doi:10.1111/nph.12200, 2013.

Tai, A. P. K., Mickley, L. J., Heald, C. L., and Wu, S.: Effect of $\mathrm{CO}_{2}$ inhibition on biogenic isoprene emission: Implications for air quality under 2000 to 2050 changes in climate, vegetation, and land use, Geophys. Res. Lett., 40, 3479-3483, doi:10.1002/grl.50650, 2013.

Thornton, J. A., Jaeglé, L., and McNeill, V. F.: Assessing known pathways for $\mathrm{HO}_{2}$ loss in aqueous atmospheric aerosols: Regional and global impacts on tropospheric oxidants, J. Geophys. Res., 113, D05303, doi:10.1029/2007JD009236, 2008.

Trowbridge, A. M., Asensio, D., Eller, A. S. D., Way, D. A., Wilkinson, M. J., Schnitzler, J.-P., and Monson, R. K.: Contribution of various carbon sources toward isoprene biosynthesis in poplar leaves mediated by altered atmospheric $\mathrm{CO}_{2}$ concentrations, PloS One, 7, e32387, doi:10.1371/journal.pone.0032387, 2012.

Unger, N.: Isoprene emission variability through the twentieth century, J. Geophys. Res.-Atmos., 118, 13606-13613, doi:10.1002/2013JD020978, 2013.

Unger, N.: Human land-use-driven reduction of forest volatiles cools global climate, Nature Climate Change, 4, 1-4, doi:10.1038/nclimate2347, 2014a.

Unger, N.: On the role of plant volatiles in anthropogenic global climate change, Geophys. Res. Lett., 41, 8563-8569, doi:10.1002/2014GL061616, 2014b.

Unger, N. and Yue, X.: Strong chemistry-climate feedbacks in the Pliocene, Geophys. Res. Lett., 41, 527-533, doi:10.1002/2013GL058773, 2014. 
Valdes, P. J., Beering, D. J., and Johnson, C. E.: The ice age methane budget, Geophys. Res. Lett., 32, L02704, doi:10.1029/2004GL021004, 2005.

van der Werf, G. R., Peters, W., van Leeuwen, T. T., and Giglio, L.: What could have caused pre-industrial biomass burning emissions to exceed current rates?, Clim. Past., 9, 289-306, doi:10.5194/cp-9-289-2013, 2013.

Voulgarakis, A., Naik, V., Lamarque, J.-F., Shindell, D. T., Young, P. J., Prather, M. J., Wild, O., Field, R. D., Bergmann, D., Cameron-Smith, P., Cionni, I., Collins, W. J., Dalsøren, S. B., Doherty, R. M., Eyring, V., Faluvegi, G., Folberth, G. A., Horowitz, L. W., Josse, B., MacKenzie, I. A., Nagashima, T., Plummer, D. A., Righi, M., Rumbold, S. T., Stevenson, D. S., Strode, S. A., Sudo, K., Szopa, S., and Zeng, G.: Analysis of present day and future $\mathrm{OH}$ and methane lifetime in the ACCMIP simulations, Atmos. Chem. Phys., 13, 2563-2587, doi:10.5194/acp-13-2563-2013, 2013.

Waelbroeck, C., Paul, A., Kucera, M., Rosell-Melé, A., Weinelt, M., Schneider, R., and Turon, J.-L.: Constraints on the magnitude and patterns of ocean cooling at the Last Glacial Maximum, Nat. Geosci., 2, 127-132, doi:10.1038/ngeo411, 2009.
Wang, Y. and Jacob, D. J.: Anthropogenic forcing on tropospheric ozone and $\mathrm{OH}$ since preindustrial times, J. Geophys. Res., 103, 31123-31135, doi:10.1029/1998JD100004, 1998.

Wang, Z., Chappellaz, J., Park, K., and Mak, J. E.: Large variations in Southern Hemisphere biomass burning during the last 650 years, Science, 330, 1663-1666, doi:10.1126/science.1197257, 2010.

Webb, R. S., Rind, D. H., Lehman, S. J., Healy, R. J., and Sigman, D.: Influence of ocean heat transport on the climate of the Last Glacial Maximum, Nature, 385, 695-699, 1997.

Weber, S. L., Drury, A. J., Toonen, W. H. J., and van Weele, M.: Wetland methane emissions during the Last Glacial Maximum estimated from PMIP2 simulations: Climate, vegetation, and geographic controls, J. Geophys. Res., 115, D06111, doi:10.1029/2009JD012110, 2010.

Wilkinson, M. J., Monson, R. K., Trahan, N., Lee, S., Brown, E., Jackson, R. B., and Fall, R.: Leaf isoprene emission rate as a function of atmospheric $\mathrm{CO}_{2}$ concentration, Glob. Change. Biol., 15, 1189-1200, doi:10.1111/j.1365-2486.2008.01803.x, 2009. 